Miller, K.G., Sugarman, P.J., Browning, J.V., et al.

Proceedings of the Ocean Drilling Program, Initial Reports Volume 174AX (Suppl.)

publications.iodp.org

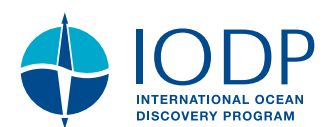

https://doi.org/10.2973/odp.proc.174AXS.111.2017

\section{Wilson Lake site ${ }^{1}$}

Kenneth G. Miller, James V. Browning, Marie-Pierre Aubry, Tali Babila, Roni D. Baluyot, Selen Esmeray-Senlet, Mark D. Feigenson, Sarp Karakaya, Christopher J. Lombardi, Maria Makarova, Steve McCreary, Peter P. McLaughlin, Donald H. Monteverde, Richard K. Olsson, Charles T. Smith, Peter J. Sugarman, and James D. Wright ${ }^{2}$

Keywords: Ocean Drilling Program, ODP, Leg 174AX, Leg 174AXS, Wilson Lake, New Jersey Coastal Plain Drilling Project, NJCPDP, Paleocene/Eocene Thermal Maximum, PETM, Cretaceous/Paleogene boundary, K/Pg, Kirkwood Formation, Shark River Formation, Manasquan Formation, Marlboro Formation, Vincentown Formation, Hornerstown Formation, Navesink Formation, Mount Laurel Formation

\section{Introduction}

The following, who are listed in alphabetic order, are responsible for the given sections:

Chief Scientists: Browning, Miller

Operations: Browning, Miller

Lithostratigraphy: Browning, McLaughlin, Miller, Sugarman

Biostratigraphy:

Foraminifers: Browning, Esmeray-Senlet, Olsson

Calcareous nannofossils: Aubry

Logging: McLaughlin

Isotopic stratigraphy: Babila, Browning, Feigenson, Makarova, Miller, Wright

\section{Site summary}

The Wilson Lake site (May 2011) was the fourteenth continuously cored borehole drilled as part of the New Jersey Coastal Plain Drilling Project (NJCPDP) and the eleventh site drilled as part of Ocean Drilling Program (ODP) Leg 174AX (Figure F1). Located immediately adjacent to the United States Geological Survey (USGS) Wilson Lake corehole (designated Hole A), Wilson Lake Hole B $\left(39^{\circ} 39.590^{\prime} \mathrm{N}, 75^{\circ} 02.830^{\prime} \mathrm{W}\right.$; Scotland Run Park, Gloucester County, New Jersey) targeted recoring the Paleocene/Eocene Thermal Maximum (PETM) and coring the Cretaceous/Paleogene (K/Pg) boundary. Total depth (TD) for Wilson Lake Hole B is $460 \mathrm{ft}(140.2 \mathrm{~m})$ with $347.59 \mathrm{ft}(105.9 \mathrm{~m})$ recovered from $455 \mathrm{ft}(138.7 \mathrm{~m})$ cored (76.4\% recovery). Recovery in the target zone for the PETM to the $\mathrm{K} / \mathrm{Pg}$ boundary (300-460 ft; 91.44-140.2 m) was $94 \%$. A full suite of slimline downhole logs was obtained on the formation to $459 \mathrm{ft}$ $(139.9 \mathrm{~m})$. A team of scientists from Rutgers University, the Delaware Geological Survey (DGS), and the New Jersey Geological and
Water Survey (NJGWS) collaborated in drilling and stratigraphic studies of this corehole that was funded by the National Science Foundation (NSF) to Rutgers and by in-kind support from the DGS.

Upper Miocene Bridgeton Formation gravels observed in adjacent outcrops were not recovered, and the base of the formation was placed in the corehole at $25 \mathrm{ft}(7.6 \mathrm{~m})$ based on gamma log values. The Cohansey Formation (25-100.2 ft; 7.6-30.5 m) was poorly recovered, has no age constraints at this site (upper middle to upper Miocene elsewhere), and consists of a clayier upper section deposited in lagoonal/estuarine environments and a sandier lower part deposited in nearshore environments.

The Kirkwood Formation (100.2-211.5 ft; 30.5-64.5 m) consists predominantly of silty clay that can be divided into three sequences. The upper sequence $(100.2-149.8 \mathrm{ft} ; 30.5-45.7 \mathrm{~m})$ was deposited in lagoonal environments and cannot be directly dated. The middle sequence (149.8-196.3 ft; 45.7-59.8 m) was primarily deposited in offshore-shoreface environments and is dated as $19.6 \mathrm{Ma}$ (range = 18.4-19.8 Ma) and can be correlated with either the Kw1a or Kw1b sequence; it is likely the latter based on $\mathrm{Sr}$ isotopic stratigraphy, suggesting the overlying sequence is the $\mathrm{Kw} 2$ sequence. A thin sandy (196.3-211.5 ft; 59.8-64.5 m) Kw0 sequence appears to represent lagoonal environments with a single $\mathrm{Sr}$ isotopic age of $22.6 \pm 0.3$ Ma.

The middle Eocene lower Shark River Formation (211.5-300.3 $\mathrm{ft}$; $64.5-91.5 \mathrm{~m}$ ) can be broken into two sequences separated by a sequence boundary at $266.0 \mathrm{ft}(81.1 \mathrm{~m})$. The upper sequence is assigned to middle middle Eocene Zone NP16 and a broad assignment to Zones E8-E9 and thus correlates with Sequence E7 of Browning et al. (1997). The upper part of the sequence consists of shelly sandy silty clay that fines downsection and has a glauconiterich interval at its base. Benthic foraminiferal Biofacies A (50 \pm 10 $\mathrm{m})$ occurs at the top with deeper Biofacies $C(100 \pm 10 \mathrm{~m})$ in the

\footnotetext{
${ }^{1}$ Miller, K.G., Browning, J.V., Aubry, M.-P., Babila, T., Baluyot, R.D., Esmeray-Senlet, S., Feigenson, M.D., Karakaya, S., Lombardi, C.J., Makarova, M., McCreary, S., McLaughlin, P.P., Monteverde, D.H., Olsson, R.K., Smith, C.T., Sugarman, P.J., and Wright, J.D., 2017. Wilson Lake site. In Miller, K.G., Sugarman, P.J., Browning, J.V., et al., Proceedings of the Ocean Drilling Program, Initial Reports, 174AX (Suppl.): College Station, TX (Ocean Drilling Program). https://doi.org/10.2973/odp.proc.174AXS.111.2017

2 Leg 174AX (Suppl.) Scientists' addresses.

MS 174AXS-111: Published 24 July 2017

This work is distributed under the Creative Commons Attribution 4.0 International (CC BY 4.0) license. (c) BY
} 
lower part. The lower sequence $(266.0-300.3 \mathrm{ft}$; $81.1-91.5 \mathrm{~m})$ is a slightly sandy fossiliferous silty clay ("ash-colored marl") at the top with a clayey glauconite sand at the base. It is assigned to lower middle Eocene Zones NP14b and E8-E9 and likely correlates with Sequence E6 (or possibly Sequence E5) of Browning et al. (1997). Benthic foraminifers suggest deep water (100-135 m paleodepth) in the lower part, shallowing upward at the top $(\sim 50 \mathrm{~m})$.

The Manasquan Formation is thin (300.3-317.5 ft; 91.5-96.77 $\mathrm{m}$ ) at Wilson Lake and appears to be dissected by unconformities. It is truncated at the top (missing Zones NP12-NP14a and Sequences E3, E4, and likely E5) and by a possible unconformity at $311 \mathrm{ft}(94.8$ $\mathrm{m})$. The top sequence $(300.3-311.0 \mathrm{ft}$; $91.5-94.8 \mathrm{~m})$ is a slightly sandy, slightly glauconitic clay assigned to Zone NP11 and thus correlated with Sequence E2. The lower sequence (311.0-317.5 ft; 94.8-96.77 $\mathrm{m}$ ) is a clayey glauconite sand assigned to nannofossil Zones NP10d and NP10a-NP10c. The Manasquan interval can be divided into a clayey Deal Member and a more glauconitic Farmingdale Member, with the boundary placed at $308 \mathrm{ft}$ (93.9 m). A major unconformity ( $317.5 \mathrm{ft}$; $96.6 \mathrm{~m}$ ) separates the Manasquan Formation from the underlying Marlboro Formation.

The Marlboro Formation $(317.5-365.7 \mathrm{ft}$; $96.6-111.47 \mathrm{~m}$ ) is a clayey fine silt with the clay fraction dominated by kaolinite and illite/smectite (Lombardi, 2013). It is assigned to Zone NP9b (lowermost Eocene). The Marlboro Formation is characterized by potentially rhythmic thin (1-3 cm thick) beds separated by millimeter-scale laminations; however, the presence of drilling artifacts (core "biscuits") separated by injections of drilling mud along planes between the beds makes interpretations of rhythmic bedding uncertain. Bulk $\delta^{13} \mathrm{C}$ values begin to decrease in a transitional lithologic interval (365.5-369.5 ft; $111.47-112.68 \mathrm{~m})$, with the sharpest $\delta^{13} \mathrm{C}$ decrease, the carbon isotope excursion (CIE), associated with the base of the Marlboro Formation $(365.7 \mathrm{ft} ; 111.4 \mathrm{~m})$. Above this, the Marlboro Formation records very low, uniform $\delta^{13} \mathrm{C}$ values (-4\% to $-5 \%$; dubbed "the core" of the CIE; Röhl et al., 2007) to $\sim 331 \mathrm{ft}$ $(\sim 101 \mathrm{~m})$, above which is the beginning of the recovery of $\delta^{13} \mathrm{C}$ values to $317.5 \mathrm{ft}(96.6 \mathrm{~m})$. Wilson Lake Hole B recovered one of the thickest $(10.5 \mathrm{~m})$ reported marine sections of "the core" of the CIE that persisted globally for a very short interval (40-80 ky, using the astronomical chronology of Katz et al. [1999] and Röhl et al. [2007], respectively), indicating that the Marlboro Formation represents a very brief interval with high sedimentation rates $(>12-24 \mathrm{~cm} / \mathrm{ky}$ using astronomical chronology and $1.8 \mathrm{~cm} / \mathrm{y}$ using chronology of Wright and Schaller [2013]).

The Vincentown Formation (365.7-389.8 ft; 111.47-119.57 m) is a slightly glauconitic, laminated to bioturbated quartzose clayey silt that becomes increasingly glauconitic downsection. It is assigned to Zone NP9 (uppermost Paleocene) and correlated to Sequence Pa3a of Harris et al. (2010). The contact with the underlying Hornerstown Formation (389.8-410.7 ft; 119.57-125.2 m) appears conformable. The Hornerstown Formation is a clayey glauconite sand that is riddled by three unconformities at 398.4, 399.6, and $403.55 \mathrm{ft}(121.4,122.54$, and $123.0 \mathrm{~m}$, respectively) separating Zones NP9a, NP4, and NP3.

The K/Pg boundary is at the base of the Hornerstown Formation $(412.0 \mathrm{ft} ; 125.6 \mathrm{~m})$ and underlain by the Maastrichtian Navesink Formation. Basal Danian Zone P0 is identified, but there is significant reworking of Maastrichtian taxa and an unconformity and coring gap immediately above the boundary (with Zones P4 and NP3 above the gap).

The Navesink Formation (410.7-431.0 ft; $125.2-131.4 \mathrm{~m}$ ) is a Maastrichtian clayey glauconite sand with common pyrite. The basal contact with the underlying Mount Laurel Formation is a lag/reworked heterolithic unit that may represent a lowstand systems tract. The hole bottomed in silty medium sand of the Mount Laurel Formation that would provide the only aquifer at this site other than the unconfined Bridgeton-Cohansey Formations.

\section{Background and objectives}

This chapter is the site report for the Wilson Lake corehole, the fourteenth continuously cored and logged onshore site drilled as part of the NJCPDP (Figure F1). The NJCPDP began with drilling at Island Beach (March-April 1993), Atlantic City (June-August 1993), and Cape May (March-April 1994) as part of ODP Leg 150X (Miller et al., 1994a, 1994b, 1996a; Miller and Snyder, 1997). These three sites targeted Oligocene-Miocene sequences and tried to unravel icehouse sea level changes tied to continental slope drilling by the R/V JOIDES Resolution during Leg 150 (Miller and Mountain, 1994; Miller et al., 1996b, 1998a).

Leg 174AX continued onshore drilling at the following locations with specific objectives:

1. Bass River, New Jersey (October-November 1996) (Miller et al., 1998b), targeting Upper Cretaceous-Paleocene strata unsampled during Leg $150 \mathrm{X}$.

2. Ancora, New Jersey (July-August 1998) (Miller et al., 1999), an updip, less deeply buried Cretaceous-Paleocene section complementary to the Bass River site.

3. Ocean View, New Jersey (September-October 1999) (Miller et al., 2001), focusing on middle Eocene-upper Miocene sequences.

4. Bethany Beach, Delaware (May-June 2000) (Miller et al., 2003), concentrating on thick Miocene sequences in the depocenter of the Salisbury Embayment.

5. Fort Mott, New Jersey (October 2001) (Sugarman et al., 2004), targeting the largely nonmarine Cretaceous Potomac Group and its contained aquifers.

6. Millville, New Jersey (May-June 2002) (Sugarman et al., 2005), targeting upper Cretaceous sequences from southern New Jersey.

7. Sea Girt (September-November 2003) (Miller et al., 2006), targeting upper Cretaceous sequences from northern New Jersey.

8. Cape May Zoo (September-October 2004) (Sugarman, et al., 2007), targeting middle Miocene-Pleistocene sequences to better define the distribution of Miocene sequences and aquifers in the Cape May peninsula.

9. Medford (April-May 2007) (Sugarman et al., 2010), located to focus on improved correlations of Cretaceous sequences and aquifers.

10. Double Trouble (October-November 2008) (Browning et al., 2011), drilled to improve understanding of Eocene aquifers.

Unlike previous Leg 150X and 174AX coreholes that focused on sea level change and aquifers, Wilson Lake Hole B "twinned" a previous hole that was drilled exclusively for study of the PETM. Wilson Lake was first drilled in 1999 to recover PETM sediments by the USGS Eastern Regional Mapping Team (drillers Gene Cobbs and Gene Cobbs III) for scientists at the USGS (T. Gibson and L. Bybell, chief scientists). Wireline logs were recorded in the original hole by P. McLaughlin of the DGS.

The Wilson Lake site has proven to be one of the most important PETM sections globally, recording an apparent precursor warming (Sluijs et al., 2007). There have been numerous publications on 
this corehole (Gibbs et al., 2006a, 2006b; John et al., 2008; Lippert and Zachos, 2007; Sluijs and Brinkhuis, 2009; Sluijs et al., 2007, 2008; Schumann et al., 2008; Zachos et al., 2006). The original USGS corehole did not penetrate below the uppermost Paleocene. A new corehole was needed because the previous Wilson Lake corehole stopped short of the K/Pg boundary and core material from the PETM section is depleted (J. Self-Trail, pers. comm., 2010).

The PETM has been identified in previous studies as occurring in the Marlboro Clay (referred to as the Marlboro Formation in this study) in parts of the Salisbury Embayment, including the New Jersey coastal plain (e.g., Kopp et al., 2009). The beginning of the PETM is associated with a rapid $2.5 \%$ o $-7 \%$ o decrease in global bulk $\delta^{13} \mathrm{C}$ values, followed by a subsequent period of low stable $\delta^{13} \mathrm{C}$ values ("the core" of Röhl et al., 2007), and an exponential recovery over 100-200 ky (e.g., Kennett and Stott, 1991; Bains et al., 1999; Katz et al., 1999; Röhl et al., 2000; Farley and Eltgroth, 2003; Murphy et al., 2010), collectively known as the CIE. The CIE and period of low $\delta^{13} \mathrm{C}$ values has been found associated with the Marlboro Clay throughout New Jersey (Cramer et al., 1999; Zachos et al., 2006; Harris et al., 2010; Makarova et al., 2017) and is especially notable in Wilson Lake Hole A (Sluijs et al., 2007).

The K/Pg boundary is remarkably complete in Leg 174AX coreholes (Olsson et al., 1997, 2002; Miller et al., 2010). The boundary is associated in the coreholes with a change from Maastrichtian glauconitic clay assigned to the Navesink or New Egypt Formations to glauconite sand of the Danian Hornerstown Formation (Olsson et al., 1997, 2002; Miller et al., 2010). In the most complete sections (e.g., Bass River; Figure F1), sand-sized spherules (altered microtektites) and shocked quartz are associated with an iridium anomaly and mass extinction of planktonic foraminifers (Olsson et al., 1997, 2002; Miller et al., 2010).

We saw an opportunity to resample the PETM and sample the $\mathrm{K} /$ Pg boundary at Wilson Lake at minimal costs. In May 2011, we cored Wilson Lake Hole B approximately $150 \mathrm{ft}$ west of the USGS 1999 Wilson Lake Hole A, bottoming in Campanian strata. We recovered the entire PETM section and the K/Pg boundary. We drilled Wilson Lake Hole B as a cooperative agreement with the DGS, the New Jersey Geological Survey, and Rutgers University (supported by NSF EAR-0744399 and OCE0751757) using the DGS rig and head driller. DGS and Rutgers personnel served as drillers helpers in addition to their usual roles of core describers, micropaleontologists, and core archivists. Integrated Ocean Drilling Program (IODP) and NSF/Ocean Drilling agreed that this corehole was of great interest to the scientific community and should be published with Leg 174AX coastal plain coreholes.

\section{Operations}

On 9 May 2011, the DGS truck-mounted CME Model 55 drilling rig arrived at Wilson Lake/Scotland Run Park, Clayton, Gloucester County, New Jersey, with Head Driller McCreary and Driller of Record Curran on site. The site was inspected and a location for the new Wilson Lake Hole B was chosen to be $\sim 150 \mathrm{ft}(45.7 \mathrm{~m})$ west of Wilson Lake Hole A. GPS coordinates for Hole A are $39^{\circ} 39.587^{\prime} \mathrm{N}$, $75^{\circ} 02.831^{\prime} \mathrm{W}$, and coordinates for Hole B are $39^{\circ} 39.590^{\prime} \mathrm{N}$, $75^{\circ} 02.830^{\prime} \mathrm{W}$. A water supply well was installed by drilling $40 \mathrm{ft}(12.2$ m) using a 4.25 inch $(10.8 \mathrm{~cm})$ auger and installing 2 inch $(5.1 \mathrm{~cm})$ diameter PVC water pipe to be extracted at completion.

The rig was placed and $4 \mathrm{ft}(1.2 \mathrm{~m})$ of steel surface casing was inserted into an augered hole. The mud and coring systems were as- sembled, drilling mud was mixed using Quick Gel, and drilling began with an inner core barrel.

There was no recovery on Runs $1(5-10 \mathrm{ft} ; 1.5-3 \mathrm{~m}), 2(10-15 \mathrm{ft}$; $3-4.6 \mathrm{~m})$, and $3(15-25 \mathrm{ft}$; 4.6-7.6 m). Run 4 (25-35 ft; 7.6-10.7 m) had excellent recovery of silty clay to clay. Run 5 (35-45 ft; $10.7-$ $13.7 \mathrm{~m})$ recovered $4 \mathrm{ft}(1.2 \mathrm{~m})$ of green silty clay. Run 6 recovered $1.65 \mathrm{ft}(0.5 \mathrm{~m})$ of intermixed clay and sand and silty clay. The day ended at $50 \mathrm{ft}(15.2 \mathrm{~m})$ with $14.35 \mathrm{ft}(4.4 \mathrm{~m})$ of core recovered $(32 \%$ of the cored section).

On 10 May, drilling Runs 7 through 15 began at $50 \mathrm{ft}$ and ended at $150 \mathrm{ft}$. Run $7(50-60 \mathrm{ft}$; $15.24-18.3 \mathrm{~m})$ recovered $2.6 \mathrm{ft}(0.8 \mathrm{~m})$ of medium sand. Run 8 (60-70 ft; $18.3-21.3 \mathrm{~m})$ recovered medium sand and sandy clay. Run $9(70-80 \mathrm{ft} ; 21.3-24.4 \mathrm{~m})$ recovered $1 \mathrm{ft}$ $(0.3 \mathrm{~m})$. After Run 9, an interval of pea gravel (noted on the Hole B [ 75-81 ft; $22.9-24.7 \mathrm{~m}]$ and Hole A [ 80-82 ft; 24.4-25 m] gamma logs) caused the loss of a significant volume of drilling mud. The driller thickened the mud and drilled 80-90 ft (24.4-27.4 m) without a core barrel. Run 10 (90-100 ft; $27.4-30.5 \mathrm{~m}$ ) recovered no core except for gravel in the shoe that is either caved from 75 to $81 \mathrm{ft}$ ( 22.9 to $24.7 \mathrm{~m}$ ) or similar zones noted on the gamma log at $~ 90-94$ and 96-99 ft (27.4-28.7 and 29.3-30.2 m, respectively). Run 11 $(100-110 \mathrm{ft} ; 30.5-33.5 \mathrm{~m})$ recovered $5 \mathrm{ft}(1.5 \mathrm{~m})$ of gray slightly silty clay of the Kirkwood Formation. The top $0.2 \mathrm{ft}(0.1 \mathrm{~m})$ of the run contained gravel and a cemented limonitic sandstone that may be caved but is interpreted as in place and is assigned to the base of the Cohansey Formation in agreement with a shift in the gamma log at $100 \mathrm{ft}(30.5 \mathrm{~m})$. Subsequent coring runs in the afternoon were rapid and without problems, obtaining excellent recovery of Kirkwood Formation clay. Run $12(110-120 \mathrm{ft} ; 33.5-36.6 \mathrm{~m})$ recovered $10.3 \mathrm{ft}$ $(3.1 \mathrm{~m})$ of core; the top $3 \mathrm{ft}(0.9 \mathrm{~m})$ was similar to above, but the bottom became slightly clayier, less laminated, and lighter gray. Run $13(120-130 \mathrm{ft} ; 36.6-39.6 \mathrm{~m})$ recovered $10.35 \mathrm{ft}$ (3.2 m), with green clay at the top and laminated silty clay at the base. Run 14 (130-140 $\mathrm{ft}$; $39.6-42.7 \mathrm{~m})$ recovered $10.25 \mathrm{ft}(3.1 \mathrm{~m})$, with laminated silty clay at the top and green clay at the bottom. Run 15 (140-150 ft; 42.7$45.7 \mathrm{~m})$ recovered $10.2 \mathrm{ft}(3.1 \mathrm{~m})$. The day ended with $51.6 \mathrm{ft}(15.7$ $\mathrm{m})$ recovered from $100 \mathrm{ft}(30.5 \mathrm{~m})$ drilled (51.6\%) but with $46.15 \mathrm{ft}$ $(14.1 \mathrm{~m})$ recovered from the last $50 \mathrm{ft}(15.2 \mathrm{~m})$ drilled $(92.3 \%)$.

Drilling began on 11 May with Run 16 (150-160 ft; 45.7-48.8 $\mathrm{m})$, which recovered $10.2 \mathrm{ft}$ ( $3.1 \mathrm{~m})$ of silty clay grading to clayey silt. Run 17 (160-170 ft; 48.8-51.8 m) contained a significant number of biscuits (cylinders of sediment core separated by a slurry of drilling fluid) caused by the inner barrel sticking to the outer core barrel while drilling. Runs 18 (170-180 ft; 51.8-54.9 m) and 19 (180-190 $\mathrm{ft} ; 54.9-57.9 \mathrm{~m}$ ) both had full recovery in finely laminated silty clay. Run 20 (190-205 ft; 57.9-62.5 m) recovered $10.4 \mathrm{ft}(3.2 \mathrm{~m})$; the driller overdrilled the run by $5 \mathrm{ft}(1.5 \mathrm{~m})$ for a $15 \mathrm{ft}$ run. Run 21 (205-210 ft; 62.5-64.0 m) was drilled short to see if we could recover any of the material lost on the last run, but no extra core was recovered (recovery of $3.7 \mathrm{ft} ; 1.1 \mathrm{~m})$. Run 22 (210-220 ft; 64.0-67.1 $\mathrm{m}$ ) had complete recovery $(10.05 \mathrm{ft} ; 3.1 \mathrm{~m})$, including a contact between sand above and sandy silty clay below.

At $220 \mathrm{ft}(67.1 \mathrm{~m})$ the rods were pulled to switch out the $5 \mathrm{ft}(1.5$ $\mathrm{m})$ rods in the hole with $10 \mathrm{ft}(3 \mathrm{~m})$ rods. The rig can only drill $5 \mathrm{ft}$ $(1.5 \mathrm{~m})$ at a time because it is limited by the length of the stroke, which is only $6 \mathrm{ft}(1.8 \mathrm{~m})$. The $5 \mathrm{ft}$ rods in the ground are replaced with $10 \mathrm{ft}$ rods, allowing the $5 \mathrm{ft}$ rods to be used at the drill head. Once $220 \mathrm{ft}(67.1 \mathrm{~m})$ of $5 \mathrm{ft}(1.5 \mathrm{~m})$ rods are drilled, they must be pulled out of the hole and replaced by $10 \mathrm{ft}(3 \mathrm{~m})$ rods. After $2 \mathrm{~h}$ for this operation and an additional hour to remove caved cuttings 
from the bottom of the hole, two additional coring runs were made. Runs 23 (220-230 ft; 67.1-70.1 m) and 24 (230-240 ft; 70.1-73.2 m) were completed in sandy silty clay at the end of the day with full recovery. The day ended with $85.5 \mathrm{ft}(26.1 \mathrm{~m})$ of core recovered from $90 \mathrm{ft}(27.4 \mathrm{~m})$ drilled (95.3\%).

On 12 May, no problems were encountered in sandy silty clay on Runs 25 (240-250 ft; 73.2-76.2 m), 26 (250-260 ft; 76.2-79.2 m), and 27 (260-270 ft; 79.2-82.3 m). Drilling slowed in glauconitic silt on Run 28 (270-280 ft; 82.3-85.3 m). Drilling ended at $1200 \mathrm{~h}$, with $40.4 \mathrm{ft}(12.3 \mathrm{~m})$ recovered from $40 \mathrm{ft}(12.1 \mathrm{~m})$ drilled (101.0\%).

Drilling operations on Friday 13 May reached into the uppermost part of the Marlboro Formation. A new pan of drilling mud was mixed, and Run 29 (280-290 ft; 85.3-88.4 m) drilled as the first of the day with full recovery $(10.2 \mathrm{ft} ; 3.1 \mathrm{~m})$. Run $30(290-300 \mathrm{ft}$; 88.4-91.4 m) recovered $9.95 \mathrm{ft}(3.0 \mathrm{~m})$ of core. Recovery on Run 31 (300-310 ft; $91.4-94.5 \mathrm{~m})$ was measured at $9.2 \mathrm{ft}(2.8 \mathrm{~m})$, though some fracturing/compression in the core from 3.8 to $4.9 \mathrm{ft}$ (1.2 to $1.5 \mathrm{~m})$ suggests recovery was closer to $9.4 \mathrm{ft}(2.9 \mathrm{~m})$. We drilled the last core on Run 32 (310-320 ft; 94.5-97.5 m) at $1230 \mathrm{~h}$ with 10.05 $\mathrm{ft}(3.1 \mathrm{~m})$ of recovery, including the contact between the Manasquan and the Marlboro Formations at $317.5 \mathrm{ft}$. The day ended with $39.45 \mathrm{ft}(12.0 \mathrm{~m})$ recovered from $40 \mathrm{ft}(12.2 \mathrm{~m})$ drilled ( $98.6 \%$ recovery). The driller conditioned the hole and pulled $100 \mathrm{ft}$ $(30.5 \mathrm{~m})$ of rods before the weekend to keep the drill string out of the zone of potential clay swelling, leaving the drill bit at $220 \mathrm{ft}(67.1$ $\mathrm{m})$.

Drilling operations resumed on Monday 16 May, beginning with the driller adding drill rods to lower the bit back to the bottom of the hole. Run 33 (320-330 ft; 97.5-100.6 m) started the day with full recovery, followed by Runs $34(330-340 \mathrm{ft} ; 100.6-103.6 \mathrm{~m}), 35$ (340-350 ft; $103.6-106.7 \mathrm{~m})$, and $36(350-360 \mathrm{ft} ; 106.7-109.7 \mathrm{~m})$ in rapid succession, all of which also had full recovery. In general, recovery was $10.4 \mathrm{ft}(3.2 \mathrm{~m})$ on these runs (104\%), reflecting core expansion, and subsequent closely spaced sampling must account for this in a modified core depth. Run 37 (360-370 ft; 109.7-112.8 m) recovered $9.79 \mathrm{ft}(3.0 \mathrm{~m})$, including the top of the Vincentown Formation sensu stricto and perfect recovery of a lithologic contact at $366 \mathrm{ft}(111.6 \mathrm{~m})$ that is likely the CIE. Run 38 (370-380 ft; $112.8-$ $115.8 \mathrm{~m})$ recovered clayey silt with $9.2 \mathrm{ft}(2.8 \mathrm{~m})$ of recovery. Runs 39 (380-390 ft; $115.8-118.9 \mathrm{~m})$ and $40(390-400 \mathrm{ft} ; 118.9-121.9 \mathrm{~m})$ recovered $10.0 \mathrm{ft}(3.0 \mathrm{~m})$ and $10.17 \mathrm{ft}(3.1 \mathrm{~m})$, respectively. A hard shelly layer was drilled slowly at $398 \mathrm{ft}(121.3 \mathrm{~m})$. On Run 41 (400$410 \mathrm{ft} ; 121.9-125.0 \mathrm{~m})$, a hard zone was encountered at $\sim 7 \mathrm{ft}(2.1 \mathrm{~m})$ and only $6 \mathrm{ft}(1.8 \mathrm{~m})$ of core was recovered; it appears we lost the bottom $4 \mathrm{ft}(1.2 \mathrm{~m})$. The day ended with Run 42 (410-420 ft; $125.0-$ $128.0 \mathrm{~m})$, which recovered $10.22 \mathrm{ft}(3.1 \mathrm{~m})$ and included the $\mathrm{K} / \mathrm{Pg}$ boundary. All-in-all, 16 May was a spectacular day with rapid drilling (100 ft; $30.5 \mathrm{~m})$, remarkable core recovery (97.5\%), and recovery of both of the major contacts that were the primary targets. The driller pulled $120 \mathrm{ft}(36.6 \mathrm{~m})$ of pipe out of the hole, leaving $300 \mathrm{ft}$ $(91.4 \mathrm{~m})$ in, to avoid being trapped by swelling clay.

On 17 May, Run $43(420-430 \mathrm{ft} ; 128.0-131.0 \mathrm{~m})$ recovered 10.3 $\mathrm{ft}(3.1 \mathrm{~m})$. Run 44 (430-438 ft; $131.0-133.5 \mathrm{~m})$ was cut short when the driller could not get mud to circulate. We pulled the rods and found that a thick clay rind had built up around the bottom of the barrel. There was a lithology change in the core to muddy sand, representing penetration to the sandier lithologies of the Mount Laurel Formation. Only $2.3 \mathrm{ft}(0.7 \mathrm{~m})$ of core was recovered from the run. Drilling in the sand was more difficult than drilling in the clay, and recovery generally decreased in the next several core runs: Runs 45
(438-440 ft; $133.5-134.1 \mathrm{~m}), 46$ (440-442.56 ft; $134.1-134.9 \mathrm{~m})$, and $47(442.56-450 \mathrm{ft} ; 134.9-137.2 \mathrm{~m})$ recovered $7.7 \mathrm{ft}(2.3 \mathrm{~m})$ in total. Runs $48(450-452.87 \mathrm{ft} ; 137.2-138.0 \mathrm{~m})$ and $49(452.9-460 \mathrm{ft}$; $138.0-140.2 \mathrm{~m})$ recovered $2.25(0.7 \mathrm{~m})$ and $7.2 \mathrm{ft}(2.2 \mathrm{~m})$ of core, respectively. On the last day of drilling we recovered $33.7 \mathrm{ft}(10.3 \mathrm{~m})$ from $40 \mathrm{ft}$ (12.2 $\mathrm{m})$ drilled (84\% recovered).

Wilson Lake Hole B bottomed at a TD of $460 \mathrm{ft}(140.2 \mathrm{~m})$ with 49 cores obtained, totaling $361.94 \mathrm{ft}(105.9 \mathrm{~m})$ recovered from $455 \mathrm{ft}$ (138.7 m) cored (79.5\% recovery). Core recovery, a short lithologic description, the formation, and color are given in Table T1. Recovery in the target zone for the PETM to K/Pg boundary (300-460 ft; 91.44-140.2 m) was $150.45(45.9 \mathrm{~m})$ out of $160 \mathrm{ft}(48.8 \mathrm{~m})$ (94\% recovery). Fifty core boxes were moved to the IODP Rutgers core repository.

Geophysical logging was conducted on 17 May by P. McLaughlin of the DGS using the DGS's Century logging tools and a Rutgers University $800 \mathrm{~m}$ Century winch housed at the DGS. With the drill rods in the hole, the gamma log tool (Model 9012A) was run inside the rods using the $300 \mathrm{~m}$ winch to a depth of $459 \mathrm{ft}(139.9 \mathrm{~m})$ and a good gamma log was obtained. The drill rods were subsequently pulled and a Gamma-Electric Multitool (Model 8144A) was run in the open hole. The down run was problematic, with power lost temporarily at around $200 \mathrm{ft}(61.0 \mathrm{~m})$ and electrical noise appearing on the resistivity logs. The equipment was rebooted and a second run was attempted. The second run encountered electrical spikes at multiple points below $200 \mathrm{ft}(61.0 \mathrm{~m})$ on the down run, and the tool was not able to pass below $422 \mathrm{ft}(128.6 \mathrm{~m})$ due to an obstruction in the hole. The uphole run obtained a mostly noise-free log from 422 $\mathrm{ft}(128.6 \mathrm{~m})$ to the surface. The driller then made two attempts to clear the obstruction at the bottom of the hole with heavy objects on the end of the wireline (cable used to retrieve the core barrel). The first attempt used the quad latch retrieval device and was unsuccessful. The second attempt used $40 \mathrm{ft}(12.2 \mathrm{~m})$ of drilling A-rod and did successfully clear the obstruction. A third run of the multitool was made using the $800 \mathrm{~m}$ winch; good logs were obtained on both down and up runs to a depth of $457.5 \mathrm{ft}(139.4 \mathrm{~m})$. The hole was pressure grouted with bentonite and abandoned on 18 May.

Analysis of the gamma logs from Hole B suggest that there is a 5-6 ft (1.5-1.8 m) offset with Hole A, with the latter being shallower. This offset is indicated by the fact the that a distinct gamma $\log$ increase at $24 \mathrm{ft}(7.3 \mathrm{~m})$ in Hole B is at $18 \mathrm{ft}(5.5 \mathrm{~m})$ in Hole A (Figure F2). Similarly, the gamma increase at the base of the Farmingdale Member is at $313 \mathrm{ft}(95.4 \mathrm{~m})$ in Hole B but at $307 \mathrm{ft}$ (93.6 $\mathrm{m})$ in Hole A.

\section{Lithostratigraphy and sequence stratigraphy}

The on-site scientific team provided preliminary descriptions of sedimentary texture, structure, color, fossil content, identification of lithostratigraphic units (New Jersey Division of Water Resources, 1990), lithologic contacts, and core photographs, illustrating sequence-bounding unconformities and facies variation within sequences (Tables T1, T2; Figures F3, F4, F5, F6, F7). Subsequent studies integrated preliminary descriptions with additional descriptions, nannofossil and planktonic foraminiferal biostratigraphy (Tables T3, T4), benthic foraminiferal biofacies studies (Table T5), isotopic stratigraphy (Tables T6, T7), and the downhole gamma log. Unconformities were identified on the basis of physical stratigraphy, 
including irregular contacts, reworking, bioturbation, major facies changes, and gamma ray peaks. Paraconformities were inferred from biostratigraphic breaks. Bulk $\delta^{13} \mathrm{C}$ isotopic records provide a means of correlating the PETM section (Figures F6, F8). Age control for the Miocene and Cretaceous is provided by Sr isotopes (Figure F9); for the Paleogene, age control is provided primarily by calcareous nannofossils supplemented by planktonic foraminifers (Figure F10; see Biostratigraphy). Age control is shown versus lithostratigraphy in Figures F9 and F10).

For the nonmarine and nearshore sections, lithofacies interpretations provide the primary means of recognizing unconformities and interpreting paleoenvironments and systems tracts. For the marine sections, biostratigraphic studies and $\mathrm{Sr}$ isotopes provide an additional means of recognizing unconformities and interpreting paleoenvironments and systems tracts.

Cumulative percent plots of sediments in the cores were computed from washed samples (Table T2). Each sample was dried and weighed before washing, and the dry weight was used to compute the percentage of sand. The sand fraction was dry sieved through a $250 \mu \mathrm{m}$ sieve, and the fractions were weighed to obtain the percent of very fine and fine versus medium and coarser sand. The sand fractions were examined using a microscope, and a visual estimate was made of the relative percentages of quartz, glauconite, carbonate (foraminifers and other shells), mica, and other materials contained in the sample. The values for these sand components given in Table $\mathbf{T} 2$ are derived by dividing the visual estimate (a whole number percentage) by the weight percent sand.

Facies changes within onshore sequences generally follow repetitive transgressive-regressive patterns (Sugarman et al., 1993, 1995) that consist of the following:

- A basal transgressive glauconite (particularly Paleogene-Upper Cretaceous sections) or quartz sand (particularly Miocene sections) equivalent to the transgressive systems tract (TST) of Posamentier et al. (1988).

- A coarsening-upward succession of regressive medial silt and upper quartz sand equivalent to the highstand systems tracts (HSTs) of Posamentier et al. (1988).

Lowstand systems tracts (LSTs) are usually absent in the coastal plain and the TSTs are generally thin. Because the TSTs are thin, maximum flooding surfaces (MFSs) are difficult to differentiate from unconformities. Shell beds and gamma ray peaks can mark both TSTs and MFSs. Flooding surfaces, particularly MFSs, may be differentiated from sequence boundaries by the association of erosion and rip-up clasts at the latter, lithofacies successions, and benthic foraminiferal changes. The transgressive surface, marking the top of the LST, represents a change from generally regressive to transgressive facies; because LST is generally absent, these surfaces are generally merged with the sequence boundaries. Where present, LSTs are recognized as generally thin, regressive, fluvial-estuarine sediments underlying TSTs and overlying sequence-bounding unconformities.

\section{Bridgeton Formation}

Age: Miocene

Interval: 0-?25 ft (0-?7.6 m)

The Bridgeton Formation is mapped near Wilson Lake (Owens et al., 1995), and Bridgeton gravels were observed in the park capping minor highs. The Hole A gamma log suggests that coarse material is restricted to $10-18 \mathrm{ft}(3.0-5.5 \mathrm{~m})$. The Hole B gamma log places the increase marking the base of the Bridgeton Formation at $25 \mathrm{ft}(7.6 \mathrm{~m})$. No core was obtained above $25 \mathrm{ft}(7.6 \mathrm{~m})$, and thus the Bridgeton Formation was not sampled in Hole B (Figure F3).

\section{Cohansey Formation}

Age: Miocene

Interval: ?25-?100.2 ft (?7.6-?30.5 m)

The Cohansey Formation was described in Wilson Lake Hole B from cores separated by long coring gaps (Figure F3). The top interval recovered $(25-28.8 \mathrm{ft}$; $7.62-8.8 \mathrm{~m}$ ) is the finest material recovered in the Cohansey Formation at Wilson Lake, consisting of yellow to light gray clay with thin silty laminae. It is more laminated at the top and more mottled at the bottom, with small $(<1 \mathrm{~mm})$ limonite concretions. This clay is interpreted as a paleosol, with the white clay likely containing kaolinite. A contact at $28.8 \mathrm{ft}(8.8 \mathrm{~m})$ separates yellowish clay from gray clay below. The contact is characterized by thin, wispy/crinkly laminations that likely mark the base of a weathering zone, with clay affected by soil zone weathering above to marginal marine clay below. The gray clay continues to $33.75 \mathrm{ft}(10.3 \mathrm{~m})$; it is massive with finely disseminated lignite/organic matter and thin discontinuous limonitic bands and submillimeter-scale limonitic concretions. We interpret the gray clay as lagoonal/estuarine or tidal flat deposits, perhaps somewhat modified by soil processes.

The lithology is sandier beneath a minor coring gap $(33.8-35 \mathrm{ft}$; $10.3-10.7 \mathrm{~m}$ ) as shown by low gamma log values below $34.0 \mathrm{ft}$ $(10.36 \mathrm{~m})$. Interbedded laminated sand and sandy clay $(35.0-38.7 \mathrm{ft}$; 10.7-11.8 $\mathrm{m}$ ) have rare burrows and common organic matter/lignite and are interpreted as lagoonal. A yellow interlaminated sandy clay to clayey sand (38.7-46.65 ft; $11.8-14.2 \mathrm{~m})$ spanning a $6 \mathrm{ft}(1.8$ $\mathrm{m}$ ) coring gap appears to represent tidal flat environments. Below a coring gap (46.65-50.0 ft; $14.2-15.2 \mathrm{~m}$ ), a yellow poorly sorted coarse quartz sand (50-50.8 ft; $15.2-15.5 \mathrm{~m}$ ) appears to represent nearshore environments. Medium sand (50.8-60.55 ft; $15.5-18.5$ $\mathrm{m})$ spanning a coring gap $(52.6-60 \mathrm{ft} ; 16.0-18.3 \mathrm{~m})$ has $1 \%$ opaque heavy minerals and is interpreted as upper shoreface deposits. Consistent very low gamma log values in the coring gap suggest continuity of the sand. Interbedded micaceous very fine sandy clay and clayey sand from 60.55 to $61.95 \mathrm{ft}$ (18.5 to $18.9 \mathrm{~m}$ ) appear to represent lagoonal/tidal flat environments. The sand/clay contact at $60.55 \mathrm{ft}(18.5 \mathrm{~m})$ appears to represent a facies shift/deepening upsection that could be a possible sequence boundary. There is a coring gap from 61.95 to $70 \mathrm{ft}(18.9$ to $21.3 \mathrm{~m})$. Coarse sand that appears to coarsen down to gravel may reflect coring disturbance $(70-70.9 \mathrm{ft} ; 21.3-21.6 \mathrm{~m})$. There is a large coring gap from 70.9 to $100 \mathrm{ft}$ ( 21.6 to $30.48 \mathrm{~m}$ ). Fine to medium gravel was observed in the mudpan but not cored; the gravel likely correlates with gamma log minima at 75-81, 90-94, and 96-99 ft (22.9-24.7, 27.4-28.7, and 29.3-30.2 m, respectively). In general, the sand and mud facies observed in the Cohansey Formation here are consistent with nearshore/marginal marine environments with no obvious deltaic influence.

\section{Kirkwood Formation}

Age: Miocene

Interval: ?100.2-211.5 ft (30.5-64.5 m)

Gray slightly silty clay of the Kirkwood Formation appears at $100.2 \mathrm{ft}$ (30.5 m; Figure F4). The interval from 100.0 to $100.2 \mathrm{ft}$ (30.5 to $30.5 \mathrm{~m}$ ) contained gravel and a cemented limonitic sandstone 
that could be caved or the base of the Cohansey Formation. A gamma log increase at this level suggests placement of the base of the Cohansey Formation near $100 \mathrm{ft}(30.5 \mathrm{~m})$. The Kirkwood Formation from 100.2 to $149.8 \mathrm{ft}$ ( 30.5 to $45.7 \mathrm{~m}$ ) is a relatively uniform, laminated greenish gray clay with finely disseminated organic matter; the lithology oxidizes to variegated red-brown. From 113 to 120 $\mathrm{ft}(34.4$ to $36.6 \mathrm{~m})$, the clay becomes lighter gray downsection and displays interlaminations ( $2 \mathrm{~cm}$ beds) of light gray clay and darker gray organic-rich clay, with the latter being more discontinuous and wavy. The section from 120 to $130 \mathrm{ft}$ ( 36.6 to $39.6 \mathrm{~m}$ ) consists of clay with whitish (pale yellow) quasiregular $15 \mathrm{~cm}$ bands transitioning downsection to more laminated slightly silty clay beds with $2 \mathrm{~cm}$ thick lighter to darker couplets (Figure F11); these oxidize to different colors of red and brown. Uniform dark clay continues to $149.8 \mathrm{ft}$ (45.7 m) except for a slightly silty, slightly sandy, organic-rich clay from 130 to $132.4 \mathrm{ft}$ (39.6 to $40.4 \mathrm{~m}$ ) with a sharp planar contact at its base. There is minimal bioturbation throughout. We interpret the environment of deposition of the clay from 100.2 to $149.8 \mathrm{ft}$ ( 30.5 to $45.7 \mathrm{~m}$ ) as back-barrier lagoon based on the fine-grained thick homogeneous nature, finely disseminated organic matter, and absence of soils and roots. The silty clay contains gypsum crystals. The core surface oxidizes to variegated colors that resemble soils; only by cutting into the core could the lithology be determined. We interpret a sequence boundary at $149.8 \mathrm{ft}$ (350.5 m; Figure F4) and tentatively correlate the sequence from 100.2 to $149.8 \mathrm{ft}$ (30.5 to $45.7 \mathrm{~m}$ ) with the Kw1b or Kw2 sequence of Miller et al. (1997) based on superposition and regional correlations.

We place a sequence boundary at $149.8 \mathrm{ft}(45.7 \mathrm{~m})$ at a contact between laminated to slightly burrowed greenish silty clay above and a shelly silty clayey fine sand bed below. Shells first appear in the core at this level, where they are very common in silty sand that fines downsection to clay from 150 to $153.5 \mathrm{ft}$ ( 45.7 to $46.8 \mathrm{~m}$ ); the silty sand was deposited in shoreface-offshore transitional environments (Figure F11). Very dark gray to black silty laminated clay occurs from 153.5 to $160 \mathrm{ft}$ ( 46.8 to $48.8 \mathrm{~m}$ ), becoming slightly sandy bioturbated silty clay (160-162 ft; 48.8-49.4 m). Homogeneous brown silty clay occurs from 162 to $171 \mathrm{ft}$ (49.4 to $52.1 \mathrm{~m}$ ). A very tight clay (171-171.7 ft; $52.1-52.3 \mathrm{~m}$ ) is associated with a gamma log peak that may mark the MFS, with the regressive HST extending from 149.8 to $171 \mathrm{ft}$ (45.7 to $52.1 \mathrm{~m}$ ). Swelling clay alternating with slightly shelly silty clay occurs from 171.7 to $180 \mathrm{ft}$ (52.3 to $54.9 \mathrm{~m}$ ). The section from 153.5 to $180 \mathrm{ft}$ ( 46.8 to $54.9 \mathrm{~m}$ ) was deposited in offshore environments. A greenish gray, slightly sandy (up to $30 \%$ ) clayey silt extends from $180 \mathrm{ft}(54.9 \mathrm{~m})$ to a contact at $186.9 \mathrm{ft}(57.0$ $\mathrm{m}$ ) and represents a shoreface-offshore transition in $\sim 25-30 \mathrm{~m}$ of water based on abundant Pseudononion pizarrensis (Table T5; Miller et al., 1997). Dark gray to black laminated slightly silty clay from 186.9 to $190.0 \mathrm{ft}$ (57.0 to $57.9 \mathrm{~m}$ ) represents a riverine-influenced shoreface-offshore transition. There is an abrupt change to a greenish micaceous sandy silt at $190 \mathrm{ft}(57.9 \mathrm{~m})$. A shelly sandy clay (190-190.8 ft; 57.9-58.2 m) appears to represent shoreface-offshore transition environments. Micaceous organic-rich clay occurs from 190.8 to $196.3 \mathrm{ft}(59.8 \mathrm{~m})$. This facies is unusual for the Kirkwood Formation, and it oxidizes to a variegated clay that appears influenced by soil processes. We tentatively interpret this facies as representing deposition in lagoonal environments. At $196.3 \mathrm{ft}$ (59.8 $\mathrm{m}$ ) a distinct contact with an irregular surface separates brown clay above from slightly shelly very sandy clay below (Figure F4). The very sandy clay contains faint laminations disrupted by burrows. This surface is interpreted as a sequence boundary, with the underlying sequence correlating to the $\mathrm{Kw0}$ sequence (Figures F4, F5).
The interval from the sequence boundary at $196.3 \mathrm{ft}(59.8 \mathrm{~m})$ to the maximum flooding surface at $171.7 \mathrm{ft}(52.3 \mathrm{~m})$, can be interpreted as a TST that records an upward deepening of environments from lagoonal to offshore. The sequence from 149.8 to $196.3 \mathrm{ft}$ (45.7 to $59.8 \mathrm{~m}$ ) has $\mathrm{Sr}$ isotopic ages that indicate correlation to the Kw1a or Kw1b sequence (see Chronology; Figure F9; Table T7).

Clayey silty quartz sand ( $60 \%$ sand) continues from 196.3 to $211.5 \mathrm{ft}$ (59.8 to $64.5 \mathrm{~m}$; Figure F4) in the Kirkwood Formation. The sand is very heavily burrowed, contains rare shell fragments and finely disseminated mica, and is greenish from 196.3 to $200.4 \mathrm{ft}$ (59.8 to $61.1 \mathrm{~m}$ ). Common gypsum occurs on the core surface from 196.3 to $200.4 \mathrm{ft}$ (59.8 to $61.1 \mathrm{~m}$ ). There is a coring gap from 200.4 to $205 \mathrm{ft}(61.1$ to $62.5 \mathrm{~m})$ and a brownish organic-rich interval from 205 to $207 \mathrm{ft}$ ( 62.5 to $63.1 \mathrm{~m}$ ) without shells or gypsum. Rare shells and gypsum occur in brownish clayey silty sand from 207 to $211.5 \mathrm{ft}$ (63.1 to $64.5 \mathrm{~m})$ that continues to a very abrupt contact at $211.5 \mathrm{ft}$ (64.5 m; Figure F11) with the light greenish clay ("marls") of the underlying Shark River Formation. The facies above $211.5 \mathrm{ft}(64.5 \mathrm{~m})$ have aspects of prodelta deposits (organic rich and micaceous) but are bioturbated and do not display laminations expected for a prodelta. Based on the heavy bioturbation and the organic-rich nature of the middle section, we tentatively interpret the environment of deposition as lagoonal. A peak in the gamma log at $\sim 204 \mathrm{ft}(62.2$ $\mathrm{m}$; Figure F5) is interpreted as the MFS, with a slightly sandier HST above. A Sr isotope age estimate of $22.6 \pm 0.3 \mathrm{Ma}$ at $210.3 \mathrm{ft}(64.1 \mathrm{~m}$; Figure F9; Table T7) indicates correlation of the sequence from 196.3 to $211.5 \mathrm{ft}$ (59.8 to $64.5 \mathrm{~m}$ ) to the Kw0 sequence of Miller et al. (1997).

\section{Shark River Formation}

Age: middle Eocene to latest early Eocene

Interval: $211.5-300.3 \mathrm{ft}(64.5-91.5 \mathrm{~m})$

The Shark River Formation was first encountered at $211.5 \mathrm{ft}$ (64.5 m; Figure F5), where it consists of greenish sandy silty clay. The fine-grained nature indicates assignment to the informal lower Shark River Formation (Browning et al., 1997). Contact with the overlying Kirkwood Formation is abrupt and irregular (Figure F11), marked by a shift from brown muddy sand above to faintly laminated fossil-rich silt and clay with rare glauconite and phosphate grains below. The upper part of this interval consists of moderately burrowed sandy $(\sim 30 \%)$ shelly clayey silt with rare $(0 \%-5 \%)$ glauconite. The sand content decreases downsection and is mostly restricted to sand-filled wispy burrows below $230 \mathrm{ft}$ (70.1 m; Figure F12). Shells are rare below $225 \mathrm{ft}(68.6 \mathrm{~m})$. Homogeneous heavily bioturbated sandy silty clay continues to $256 \mathrm{ft}(78.0 \mathrm{~m})$. Quartz dominates the sand fraction above $256 \mathrm{ft}(78.0 \mathrm{~m})$. Sand-filled burrows disappear from 252.6 to $254.6 \mathrm{ft}$ ( 77.0 to $77.6 \mathrm{~m}$ ), where the section is dominantly clay. We tentatively place the MFS at $\sim 255 \mathrm{ft}$ $(77.7 \mathrm{~m})$ just above the appearance of common glauconite, though it could be below this level. Glauconite sand becomes increasingly common (over 30\%) downsection below $256 \mathrm{ft}(78.0 \mathrm{~m})$ and further increases downsection below $262 \mathrm{ft}(80.0 \mathrm{~m})$ to a contact at $266.0 \mathrm{ft}$ $(81.1 \mathrm{~m})$. This contact is irregular and is interpreted as a sequence boundary. The glauconite sandy clay above the contact is heavily bioturbated with individual burrows ranging up to $3 \mathrm{~cm}$ in diameter. We tentatively identify the sequence from 211.5 to $266.0 \mathrm{ft}$ (64.5 to $81.1 \mathrm{~m}$ ) as Sequence E7 of Browning et al. (1997), supported by the assignment of this section to the lower part of middle Eocene Zone NP16 (see Calcareous nannofossils). The environment of deposition is offshore, most likely middle to outer neritic (30 to $>100 \mathrm{~m}$ 
paleodepth). Globobulimina dominates the benthic foraminiferal biofacies above $241 \mathrm{ft}$ (73.5 m; Table T5), suggesting assignment to Biofacies A (50 $\pm 10 \mathrm{~m})$ of Browning et al. (1997) (see Benthic foraminifers). Deeper biofacies ( $100 \mathrm{~m}$; Cibicidoides cf. pseudoungerianus and Cibicidoides cf. subspiratus) occur from $246 \mathrm{ft}(75.0 \mathrm{~m})$ to the sequence boundary, suggesting assignment to Biofacies C (100 \pm $10 \mathrm{~m}$ ) (see Benthic foraminifers), and thus shallowing upsection above $246 \mathrm{ft}(75.0 \mathrm{~m})$ in the HST.

Below the sequence boundary at $266.0 \mathrm{ft}$ (81.1 m; Figure F5), glauconite content drops to about $5 \%$ in sandy fossiliferous silty clay that is greenish gray to light brownish gray. This lithology is the ashcolored marl of Cook (1868), considered characteristic of the Manasquan Formation in that report but here placed in the lower part of the Shark River Formation, as explained below. The coarse fraction consists of glauconite sand ( $5 \%$ of total), quartz sand $(\sim 10 \%)$, and shell fragments ( 10\%; Figure F5). Glauconite decreases downsection to $274.5 \mathrm{ft}(83.7 \mathrm{~m})$ as shown on the logs (cumulative percent undersamples this change) and then increases, becomes coarser, and is concentrated in burrows downsection to $\sim 20 \%$ at $282 \mathrm{ft}(86.0 \mathrm{~m})$. A phosphate concretion occurs at $281 \mathrm{ft}$ $(85.6 \mathrm{~m})$. Glauconite further increases downsection, transitioning from an olive-brown glauconite $(>25 \%)$ clay $(282.1-283.9 \mathrm{ft}$; $86.0-$ $86.5 \mathrm{~m})$ to a dark greenish gray clayey glauconite sand (283.9-289.2 $\mathrm{ft}$; $86.5-88.1 \mathrm{~m})$. The section from 282.1 to $283.9 \mathrm{ft}$ ( 86.0 to $86.5 \mathrm{~m})$ is very heavily bioturbated with numerous horizontal burrows (Figure F12); the section below is bioturbated, though not as intensely. The glauconite sand becomes slightly clayier from 289.2 to $300 \mathrm{ft}$ (88.1 to $91.4 \mathrm{~m}$ ), with a few clayey glauconite sandy layers; the clayier layers were not sampled in the cumulative percentage (Figure F5). Bioturbation is heavy from $289.2 \mathrm{ft}(88.1 \mathrm{~m})$ to a contact at $300.3 \mathrm{ft}(91.5 \mathrm{~m})$. There is an irregular surface at the contact (Figure F12), where heavily bioturbated clayey glauconite sand overlies a tight greenish gray slightly glauconitic clay. Burrows of the glauconite sand occur in horizontal burrows (type-2 Thalassinoides; Savrda et al., 2001) up to $0.2 \mathrm{ft}(0.1 \mathrm{~m})$ below the contact. We interpret the contact at $300.3 \mathrm{ft}(91.5 \mathrm{~m})$ as a sequence boundary.

The ash-colored marl (266.0-283.9 ft; 81.1-86.5 m; Figure F5) overlying the glauconite sand could be lithostratigraphically placed either in the Shark River or Manasquan Formations. Owens et al. (1998) placed the base of the Shark River Formation at the lowermost glauconite above thick ash-colored marls; however, a similar ash-colored marl occurs in the Shark River Formation (Miller et al., 1994b). A similar succession observed at 266-300.6 ft (81.1-91.6 m) at Wilson Lake occurs in the nearby Clayton corehole, where is was assigned to Zone NP14, which straddles the lower/middle Eocene boundary (Owens and Bybell, pers. comm., 1995). Owens (pers. comm., 1995) correlated this section with the lower Shark River sequence. This implies that the sequence from 260.6 to $300.6 \mathrm{ft}$ (79.4 to $91.6 \mathrm{~m}$ ) is lower middle Eocene Sequence E6 (or possibly E5) of Browning et al. (1997). Nannofossil assignment of the sequence to lowermost middle Eocene nannofossil Zone NP14b confirms this correlation (see Biostratigraphy).

\section{Manasquan Formation}

Age: early Eocene

Interval: $300.3-317.5 \mathrm{ft}(91.5-96.8 \mathrm{~m})$

Below the sequence boundary at $300.3 \mathrm{ft}$ (91.5 m; Figures F5, F6) is an interval composed of an upper glauconitic clay and a lower glauconite sand assigned to the Manasquan Formation. Glauconitic clay extends from 300.3 to $308.0 \mathrm{ft}$ (91.5 to $93.9 \mathrm{~m}$ ) and is laminated with trace amounts of glauconite, quartz sand (up to 14\%), rare concretions, and rare thin shell fragments (Figure F6). Gypsum formed on the surface after coring, suggesting the presence of carbonate. The clay becomes darker at $304.8 \mathrm{ft}(92.9 \mathrm{~m})$ to dark greenish gray. Glauconite gradually increases downsection, especially increasing from 308 to $310 \mathrm{ft}$ ( 93.9 to $94.5 \mathrm{~m}$ ), becoming a clayey glauconite sand with a trace of quartz sand by $311 \mathrm{ft}(94.8 \mathrm{~m})$.

The glauconite sand $(\sim 308-317.0 \mathrm{ft}$; $93.9-96.6 \mathrm{~m})$ is assigned to the lowermost Eocene Farmingdale Member of the Manasquan Formation. It is associated with high gamma log values (Figure F6). The overlying clay is assigned to the Deal Member of the Manasquan Formation (Browning et al., 1997). The change from the Deal Member to the Farmingdale Member is gradational from 308 to $311 \mathrm{ft}$ (93.9 to $94.5 \mathrm{~m}$ ), though nannofossils suggest a possible hiatus and unconformity at $\sim 311 \mathrm{ft}$ (94.5 ft; Figure F10). Nannofossil samples between 301 and $310.5 \mathrm{ft}$ ( 91.7 and $94.6 \mathrm{~m}$ ) are assigned to Zone NP11; a change in nannofossil assemblages (see Biostratigraphy) below $310.5 \mathrm{ft}(94.6 \mathrm{~m})$ suggests a sequence boundary near this level (between 310.5 and $312.5 \mathrm{ft} ; 94.6$ and $95.3 \mathrm{~m}$ ). The age-depth plot (Figure F10) indicates a likely hiatus associated with this interval. We assign the sequence from 300.3 to $\sim 311 \mathrm{ft}(91.5$ to $94.8 \mathrm{~m}$ ) to Sequence E2 of Browning et al. (1997).

Glauconite increases down to an intensely burrowed glauconite sand with concretions (314.0-314.6 ft; 95.7-95.9 m) that may mark an MFS; the gamma log shows a peak at $313 \mathrm{ft}(95.4 \mathrm{~m})$, suggesting a core to downhole log offset of $\sim 1 \mathrm{ft}(0.4 \mathrm{~m}$; Figure F6). Glauconite decreases, gypsum increases, and clay increases down to a contact at $317.5 \mathrm{ft}(96.8 \mathrm{~m})$. The contact is remarkably sharp, though common rip-ups of green clay clasts extend up to $317.0 \mathrm{ft}(96.6 \mathrm{~m})$, with rare clasts to $316.5 \mathrm{ft}(96.5 \mathrm{~m})$. The contact marks the top of the Marlboro Formation and a major sequence boundary (Figure F13).

Nannofossils confirm that the glauconite sand largely correlates with Sequence E1, which is assigned to Zone NP10 here (312.5$316.5 \mathrm{ft}$; 95.3-96.5 m) and elsewhere (Browning et al., 1997). We thus identify the sequence from 311.0 to $317.5 \mathrm{ft}(94.8$ to $96.8 \mathrm{~m})$ as Sequence E1. We note that the lithologic boundary between the marl (Deal Member) and glauconite sand (Farmingdale Member) differs from the placement of the sequence boundary, in part because the lower part of Sequence E2 is a glauconite sand as is all of Sequence E1. The Manasquan Formation is quite thin at Wilson Lake (17.2 ft; $5.3 \mathrm{~m}$ ) compared to other locations and may be concatenated by hiatuses. The top is certainly truncated because it is missing Zones NP12-NP14a and Sequences E3, E4, and likely E5, with a possible unconformity at $311 \mathrm{ft}(94.8 \mathrm{~m})$.

\section{Marlboro Formation}

Age: earliest Eocene to latest Paleocene

Interval: $317.5-365.7 \mathrm{ft}(96.8-111.47 \mathrm{~m})$

Below the $317.5 \mathrm{ft}$ (96.8 m; Figure F6) unconformity is a dark green clayey fine silt with very rare glauconite and traces of mica that we assign to the Marlboro Formation. Though the term Marlboro is applied to strata generally described as clay (Marlboro Clay), grain size analysis reveals that the dominant grain size is fine silt at Wilson Lake (Lombardi, 2013) and elsewhere (Kopp et al., 2009). Kaolinite and interlayered illite-smectite are the codominant clay minerals in the Marlboro Formation at Wilson Lake (Lombardi, 2013) and elsewhere (Gibson et al., 2000; Cramer et al., 1999; Kopp et al., 2009). There is a minor color change at $318.2 \mathrm{ft}(97.0 \mathrm{~m})$, with 
a thin zone of dark greenish gray clayey silt immediately under the unconformity (317.5-318.2 ft; 96.8-97.0 m) passing downward into light greenish gray clayey silt $(318.2-320 \mathrm{ft}$; $97.0-97.5 \mathrm{~m})$. Clayey silt with rare mica and a trace of glauconite $(320-325 \mathrm{ft}$; $97.5-99.1$ $\mathrm{m})$ becomes interlaminated with thin clay laminae and clayey silt below $\sim 325 \mathrm{ft}(99.1 \mathrm{~m})$.

From $325 \mathrm{ft}(99.1 \mathrm{~m})$ to near the bottom of the formation (364.5 $\mathrm{ft} ; 111.1 \mathrm{~m}$ ), lithologies are fairly uniform, characterized by intercalated centimeter-scale clayey silt beds and millimeter-scale clay laminae. Of particular interest is the nature of the bedding in this interval (Figure F13). Beds are 1-3 cm thick (average $1.8 \mathrm{~cm}$ thick) and occur in zones of more prominent and less prominent beds (Lombardi, 2013; Wright and Schaller, 2013). Laminae that separate the beds are thin $(1 \mathrm{~mm})$, slightly irregular, shiny gummy swelling clay that continuously oozed from the core after numerous washings. It is likely that the swelling clay is a drilling artifact, representing a mixture of pulverized Marlboro Formation sediments and drilling fluids that were injected along bedding planes between core segments of clayey silt. The origin of the beds has been the subject of considerable debate both during drilling and in the literature (Pearson and Thomas, 2015; Pearson and Nicholas, 2014). They are rhythmic with $\sim 545$ (Lombardi, 2013) to 660 (Wright and Schaller, 2013) layers counted in the Marlboro Formation in Wilson Lake Hole B. It appears likely that the thin laminae reflect fluid injection, but the question remains unresolved whether these beds are entirely drilling artifacts (biscuiting) or reflect injection along bedding planes. Recent studies of updip sections of the Marlboro Formation at Mattawoman Creek, Maryland, document clear fining-upward trends in sediments cored without mud with a $\sim 2 \mathrm{~cm}$ cyclicity, documenting their primary nature at that site (Powars and Edwards, 2015).

Glauconite and fine quartz sand increase downward at the bottom of the Marlboro Formation (364.5-365.7 ft; 111.1-111.5 m) from trace amounts to several percent, followed by a gradational change to micaceous sandy silt from 365.7 to $366.6 \mathrm{ft}$ (111.5 to 111.7 $\mathrm{m}$; Figures F5, F13). The base of the Marlboro Formation is placed at $365.7 \mathrm{ft}(111.47 \mathrm{~m})$. There is a transitional interval between the Marlboro and Vincentown Formations from 365.7 to $369.5 \mathrm{ft}$ (111.47 to $111.7 \mathrm{~m}$; Figure F8) that we tentatively assign to the Vincentown Formation. There is a $5 \mathrm{~cm}$ subvertical piece of lignite at 366.6-366.75 ft (111.7-111.8 m; Figure F13). The base of the Marlboro Formation is associated with the CIE at $365.7 \mathrm{ft}$ (111.4 m; Figure F8).

We assign the section from 317.5 to $365.7 \mathrm{ft}$ (96.8 to $111.47 \mathrm{~m}$ ) to the Marlboro Formation (Figure F6). A coeval lowermost Eocene kaolinite-rich clay (e.g., Edwards, 1996) was first reported in Virginia and Maryland (Darton, 1948) and defined as the Marlboro Clay by Glaser (1971). It is clear that the coeval kaolinitic clayey silt found in the Wilson Lake corehole is thick (48.2 ft; $14.7 \mathrm{~m})$, lithologically distinct with upper and lower contacts, mappable, and found throughout much of the New Jersey coastal plain (e.g., it is found at Clayton, Medford, Millville, Bass River, Ancora, and Sea Girt sites [Gibson et al., 1993; Sugarman et al., 2010, 2005; Miller et al., 1998b, 1999, 2006]) and warrants recognition as a formation in New Jersey. However, the grain size in New Jersey is dominantly clayey silt and following protocols in New Jersey (e.g., Owens et al., 1998), we avoid the use of the term clay and apply the term Marlboro Formation to this unit.

The Marlboro Formation at Wilson Lake records very low, uniform carbon isotopic values $(-4 \%$ o to $-5 \%$ ) that postdate the CIE decrease (Figures F6, F8). The CIE initiation (base of the Eocene) is placed at the sharpest $\delta^{13} \mathrm{C}_{\text {bulk }}$ decrease associated with the base of the Marlboro Formation (365.7 ft; $111.47 \mathrm{~m}$; Figure F8), though $\delta^{13} C_{\text {bulk }}$ values begin to decrease in the uppermost Vincentown Formation (between 369.0 and $368.8 \mathrm{ft} ; 112.47$ and $112.41 \mathrm{~m}$ ) in Wilson Lake Hole B. Uniform low $\delta^{13} C_{\text {bulk }}$ values from 365.7 to $\sim 331 \mathrm{ft}$ (111.47 to $\sim 101 \mathrm{~m}$ ) appear to correlate with an interval of global low stable $\delta^{13} \mathrm{C}$ values ("the core" of Röhl et al., 2007) that comprises a short interval of time (see Chronology).

\section{Vincentown Formation}

Age: late Paleocene

Interval: $365.7-389.8 \mathrm{ft}(111.47-118.8 \mathrm{~m})$

As noted above, the Marlboro/Vincentown boundary is marked by a shift from clayey silt with minor glauconite, mica, and fine quartz sand at the base of the Marlboro Formation to distinctly sandier silt in the underlying Vincentown Formation. Overall, the Vincentown Formation consists of slightly glauconitic (2\%-4\%) sandy clayey silt with nearly $50 \%$ quartz sand (e.g., see Figure F6). It is highly bioturbated to laminated and contains scattered pyrite. Laminations are 1-6 $\mathrm{mm}$ scale and are commonly penetrated by numerous sand-filled micaceous burrows. Gypsum is very common on the core surface from 385.3 to $386 \mathrm{ft}$ (117.4 to $117.7 \mathrm{~m}$ ), which may mark an interval of dissolved shells and thus a flooding surface (possibly the MFS, see below). Below $380 \mathrm{ft}(115.8 \mathrm{~m})$, the sandy clayey silt becomes increasingly glauconitic ( 20\%), more laminated (with 3-4 mm scale laminations), and decreasingly micaceous down to clayey glauconite $(\sim 58 \%)$ sand at $\sim 389.8 \mathrm{ft}$ (118.8 m). All samples examined are assigned to Zone NP9 (uppermost Paleocene), indicating that this interval can be correlated to Sequence Pa3a of Harris et al. (2010).

\section{Hornerstown Formation}

Age: Paleocene

Interval: $389.8-412.0 \mathrm{ft}(118.8-125.6 \mathrm{~m})$

We place the base of the Vincentown Formation and the top of the Hornerstown Formation at $389.8 \mathrm{ft}(118.8 \mathrm{~m})$ at the transition from glauconite clay to clayey glauconite sand below (389.8-398.2 $\mathrm{ft}$; 118.8-121.4 m; Figure F6). The glauconite sand is intensely burrowed. The sediments of the Hornerstown Formation show a change downsection in the types of clay in the matrix, with brown clay above $396 \mathrm{ft}(120.7 \mathrm{~m})$, green clay from 396 to $398.4 \mathrm{ft}$ (120.7 to $121.4 \mathrm{~m})$, and phosphorescent green clay from 398.4 to $399.4 \mathrm{ft}$ (121.4 to $121.7 \mathrm{~m})$. Gypsum is very common on the core surface from 392 to $394 \mathrm{ft}$ (119.5 to $120.1 \mathrm{~m}$ ), especially at the base, and may mark a flooding surface (possibly the MFS) where a concentration of shells once existed. Shells are noted at 393.0 and $393.7 \mathrm{ft}$ (119.8 and $120.0 \mathrm{~m})$. Common shell fragments appear at $396.4 \mathrm{ft}(120.8 \mathrm{~m})$, continuing to $398.4 \mathrm{ft}$ (121.4 m; Figure F14). There is a lithologic contact at $398.4 \mathrm{ft}$ (121.4 m; Figures F6, F14), where darker green glauconite clay rests on phosphorescent green glauconite clay; this may represent a sequence boundary.

Large shell fragments/whole shells occur at $398.8-399.6 \mathrm{ft}$ (121.6-122.54 m); this is likely the Gryphaea dissimilis bed that has elsewhere been used by Owens et al. (1995) to mark the base of the Vincentown Formation, though we place the base of the formation at the change to dominance of glauconite sand. The shell bed may mark a sequence boundary noted at other sites, with clayey glauconite sand above. This thin unit (398.4-399.6 ft; $121.6-122.54 \mathrm{~m})$ 
may be sequence Boundary Pa2a of Harris et al. (2010), that is placed elsewhere in Zones P4a and NP6.

Clayey glauconite sand with brownish gray matrix occurs from 399.6 to $403.55 \mathrm{ft}$ (121.6 to $123.0 \mathrm{~m}$ ), where there is a contact with clayey glauconite sand with a phosphorescent green clay (vivianite?) matrix (403.55-404.5 ft; 123.0-123.3 m; Figure F7). The phosphorescent green clay may be more weathered and reflect subaerial exposure. After that the section returns to clayey glauconite sand with brownish clay matrix (403.65-406.1 ft; $123.0-123.8 \mathrm{~m})$. We speculate that there is a sequence boundary at $403.55 \mathrm{ft}(123.0 \mathrm{~m})$ separating Zone NP4 above from Zone NP3 (Figures F7, F13). Gypsum appears on the core surface from 404.7 to $406.1 \mathrm{ft}$ (123.4 to $123.8 \mathrm{~m}$ ) and may mark an MFS. Thus, the Hornerstown Formation at Wilson Lake appears to be punctuated by unconformities that include sequence boundaries at 400 and $403.55 \mathrm{ft}$ (121.9 and $123.0 \mathrm{~m}$, respectively) separating Zone NP9a and P4 (Thanetian), NP4 (Danian-Selandian), and NP3 (Danian).

Core from 410 to $420 \mathrm{ft}$ (125.0 to $128.0 \mathrm{~m}$ ) recovered the $\mathrm{K} / \mathrm{Pg}$ boundary that is placed biostratigraphically between $411.6 \mathrm{ft}$ (125.5 $\mathrm{m}$; Zone P0) and $412.0 \mathrm{ft}$ (125.6 m; uppermost Cretaceous). Basal Danian Zone P0 is identified, but there is significant reworking of Maastrichtian taxa and an unconformity and coring gap from 406.1 to $410 \mathrm{ft}$ ( 123.8 to $125.0 \mathrm{~m}$; Figure F7) immediately above the boundary (with Zone P4 and NP3 above the gap). Below the gap is a clayey black glauconite sand (410.0-410.7 ft; $125.0-125.2 \mathrm{~m})$. The section below $410.7-413.0 \mathrm{ft}(127.4-125.9 \mathrm{~m})$ is intensely bioturbated with coarser glauconite sand burrowed into clayier glauconite sand, with burrows extending to $414.0 \mathrm{ft}$ (126.2 m). Differentiating the Hornerstown Formation from the Navesink Formation is difficult at this site with black clayey glauconite sand above and below the K/Pg boundary. The section below $412 \mathrm{ft}(125.6 \mathrm{~m})$ has a tan brown matrix and more clay-lined burrows typical of the Navesink Formation, and we place the lower boundary of the Hornerstown Formation at this level, coincident with the highest occurrences of in situ Cretaceous planktonic foraminifers. Though the K/Pg interval appears to be biostratigraphically complete, it is likely not complete stratigraphically because it lacks the spherules, shocked quartz, and clay clasts found in the most complete New Jersey section downdip at Bass River (Olsson et al., 1997, 2002).

\section{Navesink Formation}

Age: Maastrichtian

Interval: $412.0-431.0 \mathrm{ft}(125.58-131.4 \mathrm{~m})$

The top of the Navesink Formation was placed at $412 \mathrm{ft}$ (125.58 $\mathrm{m}$; Figure F7), at a shift from grayish black clayey glauconite above to tannish black, slightly clayier glauconite sand below. The Navesink Formation consists of heavily bioturbated, slightly silty, clayey glauconite sand with shells and shell layers. Numerous pyrite-rich burrows occur between 412.0 and $420.0 \mathrm{ft}$ (125.58 and $128.0 \mathrm{~m}$ ). Burrows are more prominent and clay lined in the lower part of the formation below $419.0 \mathrm{ft}(127.7 \mathrm{~m})$. Shells appear at a number of levels between 423 and $429 \mathrm{ft}$ (128.9 and $130.7 \mathrm{~m}$ ). Clay increases in the section below $\sim 425 \mathrm{ft}(129.5 \mathrm{~m})$. A strontium estimate of $66.6 \pm 1.2 \mathrm{Ma}$ (where the $\mathrm{K} / \mathrm{Pg}$ boundary is $66.0 \mathrm{Ma}$; Gradstein et al., 2004) was obtained from a sample at $423.2 \mathrm{ft}(129.0 \mathrm{~m}$; Table T7), indicating a late Maastrichtian age; this is supported by the presence of upper Maastrichtian nannofossils (see Biostratigraphy).

\section{Mount Laurel Formation}

Age: Campanian

Interval: 431.0-460 ft (TD) (131.4-140.2 m)

Contact with the overlying Navesink Formation is placed at an abrupt change from glauconitic clay above to a heterolithic unit at $431.0 \mathrm{ft}$ (131.4 m; Figure F7). The heterolithic unit from 431.0 to $431.4 \mathrm{ft}$ (131.4 to $131.5 \mathrm{~m}$ ) consists of a mixture of the Mount Laurel and Navesink Formation lithologies burrowed down from above along with shell fragments. Typical Mount Laurel Formation lithologies appear below $431.4 \mathrm{ft}(131.5 \mathrm{~m})$, characterized by silty medium $(60 \%-70 \%)$ quartz sand. There is an unrecovered interval between $432.2(131.7 \mathrm{~m})$ and $438 \mathrm{ft}(133.5 \mathrm{~m})$. The top of the Mount Laurel Formation (431.4-434.0 ft; $131.5-132.3 \mathrm{~m}$ ) is siltier and contains more glauconite than the bulk of the formation below. The lowermost part of the Mount Laurel Formation sampled at Wilson Lake also appears to be slightly siltier. Despite its silty matrix, the Mount Laurel Formation appears to be a good aquifer in Wilson Lake Hole B. A strontium age estimate of $70.1 \pm 1.2 \mathrm{Ma}$ was obtained from a sample at $439.0 \mathrm{ft}$ (133.8 m; Table T7), consistent with assignment of this portion of the Mount Laurel Formation to the uppermost Campanian (boundary placed at 70.5 Ma in the Gradstein et al. (2012) timescale.

\section{Biostratigraphy Planktonic foraminifers}

Planktonic foraminifers are locally abundant in the Wilson Lake corehole (Tables T3, T4). Because of its updip location, core rarely contains age-diagnostic species. The Kirkwood Formation contains rare planktonic foraminifers. Shark River Formation samples are well preserved with abundant specimens. Manasquan Formation samples contain few specimens and the unit was not examined in detail. The Marlboro Formation contained a diverse planktonic foraminiferal fauna. The Vincentown Formation is barren of planktonic foraminifers. The Hornerstown and Navesink Formations were examined to assess whether the $\mathrm{K} / \mathrm{Pg}$ boundary had been recovered. A detailed biostratigraphy of the boundary will be completed at a later time.

Kirkwood Formation samples contain planktonic foraminifers in a sample at $186 \mathrm{ft}(56.7 \mathrm{~m})$. The sparse fauna contains Globigerinoides and Globoquadrina indicating a Miocene age, in agreement with strontium isotopic age estimates.

The Shark River Formation $(211.5-300.3 \mathrm{ft}$; 64.5-91.5 m) contains an abundant fauna that is difficult to zone (Table T3) because marker species are rare and species are mixed in samples that do not have overlapping ranges (Pearson et al., 2006). Species encountered generally range from the lower to middle Eocene (Zones E8 and E9 [P10 and P11]). Common species include Acarinina bullbrooki, Acarinina coalingensis, Acarinina pentacamerata, Morozovelloides coronatus, Pseudohastigerina micra, Pseudohastigerina wilcoxensis, Subbotina eocaena, Turborotalia frontosa, and Turborotalia possagnoensis.

The Manasquan Formation (300.3-317.5 ft; 91.5-96.8 m) contains few planktonic foraminifers and could not be zoned (Table T4). The Marlboro Formation (317.5-366.6 ft; $91.5-111.4 \mathrm{~m}$ ) is assigned to Zone E1 based on the first occurrence of Acarinina sibai- 
yaensis at $360.2 \mathrm{ft}(109.8 \mathrm{~m})$. The sample at $365 \mathrm{ft}(111.3 \mathrm{~m})$ contained few foraminifers and could not be zoned.

The Vincentown Formation (366.6-389.8 ft, 111.4-119.57 m) was barren for foraminifers. One sample $(396 \mathrm{ft} ; 120.7 \mathrm{~m})$ in the Hornerstown Formation (389.8-410.7 ft, 119.57-125.2 m) was found to contain Globanomalina pseudomenardii and is assigned to Zone P4 (Table T4). Samples at 405.9 and $410 \mathrm{ft}$ (123.7 and $125.0 \mathrm{~m}$, respectively) contain Danian planktonic foraminifers and samples at 412 and $413.54 \mathrm{ft}$ (125.6 and $126.0 \mathrm{~m}$, respectively) contain Cretaceous planktonic foraminifers.

In Wilson Lake Hole B, the K/Pg boundary lies between samples at 411.6 and $412 \mathrm{ft}$ (125.46 and $125.58 \mathrm{~m}$; Table T4). The paleodepth is estimated as middle to inner shelf environment of deposition. There is much reworking of Maastrichtian planktonic foraminifers into the Danian. The Maastrichtian lacks keeled species such as Globotruncana and Globotruncanita. Maastrichtian species of Heterohelix and Rugoglobigerina are most abundant with species of Globigerinelloides, Globotruncanella, and Pseudoguembelina rarer. The Danian is identified in a sample at $412 \mathrm{ft}(125.46 \mathrm{~m})$ by the occurrence of Eoglobigerina eobulloides, Globanomalina archeocompressa, Globoconusa daubjergensis, Guembelitria cretacea, Hedbergella monmouthensis, and Parasubbotina aff. pseudobulloides. These species identify Zone P0 (Table T4).

\section{Calcareous nannofossils}

Calcareous nannofossil biozonal assignments of the Paleogene to Upper Cretaceous section recovered at Wilson Lake are based on the examination of 112 samples from which smear slides were prepared and examined in bright field and cross-polarized light, using magnification of $600 \times$ and $1200 \times$ for taxonomic determination and $400 \times$ during extensive search for large marker species such as Heliodiscoaster lodoensis and Nannotetrina fulgens.

Six samples taken at 5-10 ft (1.5-3 m) intervals between 26 and $61 \mathrm{ft}(7.9$ and $18.6 \mathrm{~m})$ were barren of coccoliths, as were samples taken at $1 \mathrm{ft}(30 \mathrm{~cm})$ intervals between 189.4 and $211.1 \mathrm{ft}$ (57.7 and $64.3 \mathrm{~m}$; base of the Kirkwood Formation). Coccolith assemblages were first encountered at $216.1-216.2 \mathrm{ft}(65.87-65.90 \mathrm{~m})$ in the Shark River Formation and were continuously present down to $372.5 \mathrm{ft}(113.5 \mathrm{~m})$ in the top of the Vincentown Formation. The $14 \mathrm{ft}$ $(4.3 \mathrm{~m})$ interval between 374.5 and $388.5 \mathrm{ft}(114.1$ and $118.4 \mathrm{~m})$ was essentially barren, although a few coccoliths were encountered at $386.5,387$, and $388 \mathrm{ft}(117.8,118.0$, and $118.3 \mathrm{~m})$. Coccoliths were few to common between 389 and $392 \mathrm{ft}$ (118.6 and $119.5 \mathrm{~m}$ ); they were common to abundant between 392.5 and $420.7 \mathrm{ft}$ (119.6 and $128.2 \mathrm{~m}$ ) in the Hornerstown and Navesink Formations, respectively.

The interval between 216.1 and $261.1 \mathrm{ft}$ ( 65.87 and $79.58 \mathrm{~m}$ ) is assigned to Zone NP16 based on the presence of Chiasmolithus solitus, which is common in all samples, and the absence of Blackites gladius. In this interval, coccoliths are abundant, generally well preserved, and assemblages are of high diversity. These include Blackites creber, Blackites perlongus, Blackites scabrosus, Campylosphaera dela, Chiasmolithus expansus, Coccolithus eopelagicus, Coccolithus formosus, Helio-discoaster distinctus, Helio-discoaster saipanensis, Helicosphaera lophota, Neococcolithes dubius, Pontosphaera spp., Reticulofenestra samodurovi, Trochoaster operosus, and Zygrhablithus bijugatus. In addition, the upper samples (216.1$216.2 \mathrm{ft}$; 65.87-65.90 m) yielded Reticulofenestra reticulata, which characterizes a level in mid Zone NP16, and Reticulofenestra floridana, which occurs between samples at 226 and $246 \mathrm{ft}$ (68.9 and
$75.0 \mathrm{~m})$. The frequency and diversity of the holococcoliths reflect good preservation.

There is a sharp change in the composition of the assemblages and a marked decrease in the quality of preservation of the coccoliths between 261.0 and $261.1 \mathrm{ft}$ (79.55 and $79.58 \mathrm{~m}$; Zone NP16) and between 266.1 and $266.2 \mathrm{ft}(81.11$ and $81.14 \mathrm{~m})$. Samples at $271.0-271.1 \mathrm{ft}(82.6-82.63 \mathrm{~m})$ yielded an assemblage similar to that in samples at $266.1-266.2 \mathrm{ft}(81.11-81.14 \mathrm{~m})$. Despite the abundance of coccoliths in the $\sim 5 \mathrm{ft}(1.5 \mathrm{~m})$ interval below samples at $261.0-261.1 \mathrm{ft}(79.55-79.58 \mathrm{~m})$, it is not possible to confidently determine a zonal age. No Reticulofenestra species were encountered, nor any marker of Zone NP15. Noteworthy were the presence of Trochoastrites hohnensis and Helio-discoaster septemradiatus.

The interval between 276.0 and $276.1 \mathrm{ft}$ ( 84.12 and $84.16 \mathrm{~m}$ ) and between 296.0 and $296.1 \mathrm{ft}(90.2$ and $90.3 \mathrm{~m}$ ) belongs to Zone $\mathrm{NP14b}$, characterized by the presence of Helio-discoaster sublodoensis and Blackites inflatus (rare in samples at 280.0-280.1 ft; 85.34-85.37 m) and the absence of H. lodoensis and Helio-discoaster kuepperi (both species markers of Subzone NP14a). H. sublodoensis is common, with five- and six-rayed morphotypes. Coccoliths are abundant and well preserved, and the assemblages are typical of lower middle Eocene assemblages deposited in epicontinental settings (including Blackites tenuis, Braarudosphaera bigelowii, H. lophota, Helicosphaera seminulum, Pontosphaera fimbriata, and $T$. hohnensis). Nannotetrina cristata occurred in samples at 276.0$276.1 \mathrm{ft}(84.12-84.16 \mathrm{~m})$.

The interval between samples at 301.0-301.1 and $310.5-310.6 \mathrm{ft}$ (91.74-91.78 and 94.6-94.7 m; Manasquan Formation) is assigned to Zone NP11. Coccoliths are abundant to common and well preserved. Tribrachiatus orthostylus is very common together with Chiasmolithus consuetus, Chiasmolithus eograndis, C. solitus, C. formosus, Ellipsolithus macellus, Helio-discoaster barbadiensis, $\mathrm{He}$ lio-discoaster binodosus, H. kuepperi, Helio-discoaster pacificus, and Pontosphaera spp. A single asterolith encountered at 301.0$301.1 \mathrm{ft}$ (91.74-91.78 m) showed affinity to $H$. lodoensis but was atypical of this species.

The occurrence of Tribrachiatus contortus without T. orthostylus indicates that the sample at $312.5 \mathrm{ft}(95.25 \mathrm{~m})$ is well into Subzone NP10d, whereas the presence of Tribrachiatus bramlettei in the sample at $314.7 \mathrm{ft}(95.92 \mathrm{~m})$ characterizes Subzone NP10a or NP10c. Coccoliths are abundant and well preserved in these two samples as well as at $316.5 \mathrm{ft}(96.5 \mathrm{~m})$, which did not yield T. bramlettei or Fasciculithus tympaniformis. Based on the absence of the latter species, this sample is assigned to Zone NP10a or NP10c as well.

The interval between 317.75 and $393 \mathrm{ft}$ (96.9 and $119.8 \mathrm{~m}$ ) belongs to Zone NP9, between the highest occurrence (HO) of F. tympaniformis (at $317.75 \mathrm{ft} ; 96.9 \mathrm{~m}$ ) and the lowest occurrence (LO) of Helio-discoaster multiradiatus at $393 \mathrm{ft}(119.8 \mathrm{~m})$. Coccoliths are very well preserved from 317.75 to $354.5 \mathrm{ft}$ ( 96.9 to $108.1 \mathrm{~m}$ ), but they vary in abundance from few to common. Rhomboaster spp. (Rhomboaster calcitrapa in particular), Helio-discoaster anartios, and Helio-discoaster araneus are frequent between samples at 328.5 and $354.5 \mathrm{ft}(100.1$ and $108.1 \mathrm{~m})$. These species constitute the socalled "RD" characteristic of Subzone NP9b. R. calcitrapa was common at $317.75,319.5$, and $321.3 \mathrm{ft}(96.9,97.38$, and $97.93 \mathrm{~m})$, but only uncharacteristic specimens of $H$. araneus were recovered from these levels. Because coccoliths were very rare in them, it would be premature to interpret these data as indicative of Subzone NP9c. 
The NP9a/b subzonal boundary is defined by the HO of Fasciculithus alanii that in most sections is coincident with the LO of the $\mathrm{RD}$ assemblage. The $\mathrm{HO}$ of $F$. alanii is located at $368.5 \mathrm{ft}(112.32 \mathrm{~m})$, whereas the LO of the RD assemblage is at $354.5 \mathrm{ft}(108.1 \mathrm{~m})$. Thus, there is a $14 \mathrm{ft}(4.3 \mathrm{~m})$ interval that cannot be characterized in terms of the subzone of Zone NP9. A few specimens assignable to Fasciculithus sp. cf. F. alanii were encountered at $360.5 \mathrm{ft}(109.9 \mathrm{~m})$, whereas specimens assignable to Helio-discoaster sp. cf. H. araneus were encountered at 361.5 and $362.5 \mathrm{ft}$ (110.19 and $110.49 \mathrm{~m}$ ).

Coccoliths are abundant and well preserved at 368.5 and $369.5 \mathrm{ft}$ (112.3 and $112.6 \mathrm{~m}$ ), but abundance decreases sharply below, possibly as a corollary of poor preservation as a result of dissolution. Most samples between 374.5 and $389 \mathrm{ft}$ (114.1 and $118.6 \mathrm{~m}$ ) are essentially barren. Below this, coccoliths are more common but with moderate to poor preservation down to the sample at $392.05 \mathrm{ft}$ $(119.50 \mathrm{~m})$. In contrast, coccoliths are abundant and well preserved in samples at 392.5 and $393 \mathrm{ft}$ (119.6 and $119.8 \mathrm{~m}$ ), which yield highly diversified assemblages characteristic of Subzone NP9a.

Samples at 401.0-401.1 ft (122.22-122.26 m) are assignable to Zone NP4, comprised between the LOs of E. macellus and F. tympaniformis. Taxa characteristic of the upper part of the zone (i.e., Diantholitha spp., Lithoptychius spp., and Sphenolithus primus) were not encountered, implying that $401 \mathrm{ft}(122.22 \mathrm{~m})$ belongs to Subzone NP4a.

The assemblages recovered from 405.9 to $406 \mathrm{ft}$ (123.72 to $123.75 \mathrm{~m}$ ) yielded Cruciplacolithus tenuis and Chiasmolithus danicus together with Coccolithus ovalis, Cyclagelosphaera margerelii, Cyclagelosphaera reinhardtii, Futyania sp., Markalius astroporus, and Markalius inversus, among others. It is assigned to Zone NP3.

Samples at 412.0-412.1, 416.0-416.1, and 420.6-420.7 ft (123.72-123.75, 125.58-125.61, 126.80-126.83, and 128.20-128.23 $\mathrm{m}$, respectively) yielded abundant and well preserved coccoliths typical of the Upper Cretaceous. The presence of Nephrolithus frequens characterizes the upper Maastrichtian.

\section{Benthic foraminifers}

The Kirkwood Formation contains benthic foraminifers from 161 to $191 \mathrm{ft}$ ( 48.3 to $57.3 \mathrm{~m}$ ) in the Kw1a or Kw1b sequence (Table T5). Samples from this interval all contain abundant P. pizarrensis, indicating 25-50 $\mathrm{m}$ water depth. Buliminella elongata $(50-80 \mathrm{~m}$ paleowater depth) is also abundant in samples at $181-186 \mathrm{ft}$, indicating the greatest water depth in this sequence. Thus, according to the benthic foraminifers the deepest water in the sequence is somewhat lower that the MFS that is tentatively placed at $170 \mathrm{ft}$. The muddy facies at the base of the sequence is barren for foraminifers.

Benthic foraminifers are common in the Shark River Formation. Sequence E7 (211.5-266 ft; 64.5-81.1 m) contains an abundant benthic fauna. The base of the sequence is dominated by $C$. cf. pseudoungerianus ( $100 \mathrm{~m}$ water depth; benthic foraminiferal Biofacies C of Browning et al., 1997) and C. cf. subspiratus ( 135 m water depth; benthic foraminiferal Biofacies A of Browning et al., 1997), representing the deepest water in the sequence in agreement with the lithologic evidence for the maximum flooding surface at $255 \mathrm{ft}(77.7 \mathrm{~m})$. The benthic biofacies show evidence for shallowing upsection in this sequence with a change to a Globobulimina-dominated biofacies ( $\sim 50 \mathrm{~m}$ paleowater depth) and a Cibicidina-dominated biofacies in the upper half of the sequence (Browning et al., 1997).

Sequence E6 from the Shark River Formation (266-300.3 ft; 81.1-91.5 m) contains a benthic fauna that includes C. cf. pseudoun- gerianus, Alabamina, Anomalinoides, and Gyroidinoides, indicating a middle to outer neritic environment (Table T5).

Benthic foraminifers were not examined below the Shark River Formation because the sediments were generally poorly fossiliferous.

\section{Isotopic stratigraphy}

$\mathrm{Sr}$ isotopic age estimates were obtained from mollusk shells (Table T7). Approximately 4-6 mg of shells were cleaned using an ultrasonic bath and $\mathrm{HCl}$ and dissolved in $1.5 \mathrm{~N} \mathrm{HCl}$. Sr was separated using standard ion exchange techniques (Hart and Brooks, 1974). The samples were analyzed on an Isoprobe T Multicollector (TIM). Internal precision on the Isoprobe for the data set averaged 0.000007 , and the external precision is approximately \pm 0.000008 (based on replicate analyses of standards). NBS 987 is measured for these analysis at 0.710241 normalized to ${ }^{86} \mathrm{Sr} /{ }^{88} \mathrm{Sr}$ of 0.1194 . Strontium isotopic stratigraphy is useful for assigning ages to sediments in time periods, such as the Miocene and Cretaceous, where the ${ }^{87} \mathrm{Sr} /{ }^{86} \mathrm{Sr}$ ratio was changing rapidly. Ages are reported to the Gradstein et al. (2012) timescale using the strontium look-up tables of McArthur et al. (2001, and pers. comm., 2016). Error estimate for the Miocene samples measured here are \pm 0.25 My for $17.5-20 \mathrm{Ma}$ and $\pm 0.3 \mathrm{My}$ for 21.5-23 Ma (Browning et al., 2013) and for the Maastrichtian-Campanian are \pm 1.2 My (Sugarman et al., 1995).

Carbonate shells were first encountered in Wilson Lake Hole B in the Miocene at $150 \mathrm{ft}(45.7 \mathrm{~m})$ and eight $\mathrm{Sr}$ isotopic ages were obtained between $150 \mathrm{ft}(45.7 \mathrm{~m})$ and $210.3 \mathrm{ft}(64.1 \mathrm{~m})$ (see Table $\mathrm{T} 7)$. A sample at $165.5 \mathrm{ft}(50.4 \mathrm{~m})$ gives an age that is 1 My younger than other samples and it is assumed to have been altered and is excluded from further analysis. $\mathrm{Sr}$ isotopic age estimates suggest correlation of the sequence from 149.8 to $193.3 \mathrm{ft}$ (45.66 to $58.92 \mathrm{~m}$ ) to either the Kw1a or Kw1b sequence of Miller et al. (1997): four samples give ages of 19.5-19.8 $\pm 0.25 \mathrm{Ma}$ that are more compatible with the Kw1a sequence, whereas three samples give ages of 18.4-19.4 \pm $0.25 \mathrm{Ma}$ that are more compatible with the Kw1b sequence. The interpretation of these data is given below in Chronology.

Two Sr isotopic ages were obtained on shell material in the Navesink Formation. The sample at $427.9 \mathrm{ft}(130.4 \mathrm{~m})$ has a $\mathrm{Sr}$ ratio (0.707866) that is higher than any Cretaceous ratios reported by McArthur et al. (2001) (i.e., 0.707830). This sample is assumed to be altered. The sample at $423.2 \mathrm{ft}(129.0 \mathrm{~m})$ gives an age of $66.6 \pm 1.2$ Ma, consistent with the Navesink II sequence of Miller et al. (2004). A Sr isotopic age was also obtained on a shell in the Mount Laurel Formation. The sample at $439 \mathrm{ft}(133.8 \mathrm{~m})$ gives an age of $70.2 \pm 1.2$ $\mathrm{Ma}$, consistent with regional correlations of this unit to the uppermost Campanian (boundary at $70.5 \mathrm{Ma}$ ).

Bulk stable isotopic data (Figures F6, F8) were reported by Wright and Schaller (2013) and were generated on bulk samples (Table T6). As noted above, the initiation of the CIE is placed at a large (2.2\%) sharp $\delta^{13} \mathrm{C}_{\text {bulk }}$ decrease at $365.7 \mathrm{ft}(111.47 \mathrm{~m})$. However, bulk $\delta^{13} \mathrm{C}$ values begin to decrease in the transitional lithology tentatively assigned to the Vincentown Formation between 368.0 and $369.0 \mathrm{ft}(112.17$ and $112.47 \mathrm{~m}$ ), with a total change of $\sim 2 \%$ by 365.7 $\mathrm{ft} ; 111.47 \mathrm{~m})$. A similar precursor $\delta^{13} \mathrm{C}$ decrease occurred at the Millville site (Figure F15; Wright and Schaller, 2013) and the Ancora site (Makarova et al., 2017), though such a precursor decrease is lacking in most deep sea sections, including the thickest open ocean ODP Site 690 on the Maude Rise (Bains et al., 1999). This precursor may be attributed to the higher resolution records in New Jersey, for the CIE sections at the Wilson Lake and Millville sites are 
$\sim 15 \mathrm{~m}$ thick versus $<4 \mathrm{~m}$ at Site 690 . Alternatively, it is possible that the transitional lithologies in the interval $365.7-369.5 \mathrm{ft}$ (111.47$112.62 \mathrm{~m}$ ) reflect stratigraphic mixing.

Low $\delta^{13} C_{\text {bulk }}$ values characterize much of the Marlboro Formation, allowing correlation of "the core" (Figure F15) of Röhl et al. (2007). Based on benthic foraminiferal biofacies and stable isotope analyses, Stassen et al. $(2012,2015)$ identified no $\delta^{13} \mathrm{C}$ recovery in Wilson Lake Hole A; however, the $\delta^{13} \mathrm{C}$ record from Wilson Lake Hole B (Wright and Schaller, 2013), shows at least partial recovery values. We thus assign the section from 331.3 to $365.7 \mathrm{ft}$ (101.0 to $111.47 \mathrm{~m}$ ) to "the core" and the section from 317.5 to $331.3 \mathrm{ft}$ (96.77 to $101.0 \mathrm{~m}$ ) to the "recovery."

It should be noted that Wilson Lake Hole B recovered a thick $(\sim 10.5 \mathrm{~m})$ marine section of "the core." The section at Millville $(\sim 10$ $\mathrm{m})$ also stands out for its remarkable thickness.

\section{Chronology}

We derive a preliminary chronology and sedimentation rates of Wilson Lake Hole B using two age-depth plots. The Miocene agedepth plot was computed entirely using $\mathrm{Sr}$ isotope analyses (Figure F9). A linear fit through the Kw1 (a or b) sequence from 149.8 to $196.3 \mathrm{ft}$ (45.7 to $59.8 \mathrm{~m}$ ) was computed after discarding two points (open circles in figure), yielding ages for this sequence of 19.1-19.5 $\mathrm{Ma}$ and suggesting correlation to the Kw1b sequence and sedimentation rates of $33 \mathrm{~m} / \mathrm{My}$. We used this sedimentation rate and a $\mathrm{Sr}$ isotope age of $22.6 \pm 0.3 \mathrm{Ma}$ to estimate an age of 22.5-22.6 Ma for the Kw0 sequence from 196.3 to $211.5 \mathrm{ft}$ (59.8 to $64.5 \mathrm{~m}$ ). For the Paleogene and Upper Cretaceous, we made a visual fit through nannofossil zones (blue bars; Figure F10), a few available nannofossil $\mathrm{LO}$ and $\mathrm{HO}$ levels, and levels constrained by geochemical data (Sr ages $\pm 1.2 \mathrm{My}$ and the initiation of the CIE at $365.7 \mathrm{ft}[111.74 \mathrm{~m}]$, $56.0 \mathrm{Ma}$; the top of stable $\delta^{13} \mathrm{C}$ values ["the core"] at $331.66 \mathrm{ft}$ [101 $\mathrm{m}$ ], $55.92 \mathrm{Ma}$ ). The best constrained sequences (e.g., 311-317.5 ft; $94.8-96.8 \mathrm{~m}$ ) are fit by a rate of $20 \mathrm{~m} / \mathrm{My}$, which was assumed for other sequences. This assumption fits all of the data except for the following:

- The lower Marlboro Formation ( 331-365.7 ft; 101-111.74 $\mathrm{m})$ accumulated with the period of stable isotope values ( 4080 ky; Katz et al., 1999; Röhl et al., 2007) with a sedimentation rate of $>120-240 \mathrm{~m} / \mathrm{My}(12-24 \mathrm{~cm} / \mathrm{ky})$ or greater.

- The $\delta^{13} \mathrm{C}$ recovery interval $(317.5$ to $\sim 331 \mathrm{ft} ; 96.8$ to $\sim 101 \mathrm{~m})$ is globally on the order of 100-200 ky (Katz et al., 1999; Röhl et al., 2007), yielding sedimentation rates of $4 \mathrm{~cm} / \mathrm{ky}$; this interval is likely truncated by the unconformity at $317.5 \mathrm{ft}(96.8 \mathrm{~m})$ because the values do not show the full recovery.

- Deposition across the K/Pg boundary must have been punctuated by a hiatus given that the section between Zone NP3 and the $\mathrm{K} / \mathrm{Pg}$ boundary is very thin $(8.5 \mathrm{ft} ; 2.6 \mathrm{~m})$ for its duration (66.05 to 64.7-63.3 Ma; 0.9-1.9 m/My). In general, as an updip location, Paleogene sequences are generally thinner and temporally less complete than their downdip counterparts, with the notable exception of the Marlboro Formation.

\section{Conclusions}

Wilson Lake Hole B accomplished its primary objectives of resampling the PETM and sampling the K/Pg boundary. The K/Pg boundary was recovered at the base of the Hornerstown Formation (412 ft; $125.6 \mathrm{~m})$, but it is likely not entirely stratigraphically complete. Basal Danian Zone P0 is identified, but there is significant re- working of Maastrichtian taxa and a coring gap immediately above the boundary (with Zone P4 and NP3 above the gap). The Paleocene section is thin and highly dissected by unconformities.

For the PETM section, $100 \%$ recovery and fresh core allows closely spaced $(0.2-1.0 \mathrm{ft} ; 6-30 \mathrm{~cm})$ samples for stable isotopes across the PETM (Figures F7, F8) and even closer spacing (millimeter scale) in some intervals (Wright and Schaller, 2013). The distinct $\sim 2 \mathrm{~cm}$ thick beds noted in Wilson Lake Hole B and at the Leg 174AX Millville site (Wright and Schaller, 2013) may be a drilling artifact, but they appear to be primary with drilling mud injected along bedding planes bedding planes. The CIE $\delta^{13} \mathrm{C}$ decrease (base of the Eocene) is coincident with the base of the Marlboro Formation at $365.7 \mathrm{ft}$ (111.74 m; Figure F8). Very low uniform carbon isotopic values $(-4 \%$ o to $-5 \%$ ) in the Marlboro Formation appear to correlate with an interval of low global $\delta^{13} \mathrm{C}$ values ("the core") and a short interval of time (40 or $80 \mathrm{ky}$ using the astronomical timescale of Katz et al. [1999] or Röhl et al. [2007], respectively; <1 ky using the chronology of Wright and Schaller [2013]), indicating exceptionally high sedimentation rates $(>12-24 \mathrm{~cm} / \mathrm{ky}$ using the astronomical chronology and $1.8 \mathrm{~cm} / \mathrm{y}$ using chronology of Wright and Schaller [2013]).

Above the Marlboro Clay, the lower Eocene Manasquan Formation is thin, with Sequences E1 (Farmingdale Member) and E2 (Deal Member) deposited in a deep (>100 m paleodepth) shelf setting. The top of the Manasquan Formation is dissected by unconformities (Sequences E3, E4, and likely E5 are missing).

The middle Eocene Shark River Formation recovered two sequences (E6 [Zone NP14b] and E7 [Zone NP16]) deposited. The lower sequence was deposited on a deep shelf $(\sim 100 \mathrm{~m})$, whereas the upper was deposited in a mid-shelf (50-100 m) setting.

The Miocene Kirkwood Formation is represented by three sequences: Kw0, Kw1a/1b ( 19.6 Ma), and Kw1b or Kw2. The lower sequence was deposited in lagoonal environments. The middle sequence was deposited in shoreface-offshore shelf environments, whereas the upper was deposited in lagoonal environments. The upper middle to upper Miocene Cohansey Formation was poorly recovered and undated; it was deposited in shoreface, tidal flat, and lagoonal environments. The sections are capped by upper Miocene fluvial gravels that were not cored.

\section{References}

Bains, S., Corfield, R.M., and Norris, R.D., 1999. Mechanisms of climate warming at the end of the Paleocene. Science, 285(5428):724-727. http://dx.doi.org/10.1126/science.285.5428.724

Berggren, W.A., Kent, D.V., Swisher, C.C., III, and Aubry, M.-P., 1995. A revised Cenozoic geochronology and chronostratigraphy. In Berggren, W.A., Kent, D.V., Aubry, M.-P., and Hardenbol, J. (Eds.), Geochronology, Time Scales and Global Stratigraphic Correlation. Special PublicationSEPM (Society of Sedimentary Geology), 54:129-212. http://dx.doi.org/10.2110/pec.95.04.0129

Browning, J.V., Miller, K.G., and Olsson, R.K., 1997. Lower to middle Eocene benthic foraminiferal biofacies and lithostratigraphic units and their relationship to sequences, New Jersey coastal plain. In Miller, K.G., and Snyder, S.W. (Eds.), Proceedings of the Ocean Drilling Program, Scientific Results, 150X: College Station, TX (Ocean Drilling Program), 207-228. http://dx.doi.org/10.2973/odp.proc.sr.150X.333.1997

Browning, J.V., Miller, K.G., Sugarman, P.J., Barron, J., McCarthy, F.M.G., Kulhanek, D.K., Katz, M.E., and Feigenson, M.D., 2013. Chronology of Eocene-Miocene sequences of the New Jersey shallow shelf: implications for regional, interregional, and global correlations. Geosphere, 9(6):14341456. http://dx.doi.org/10.1130/GES00857.1 
Browning, J.V., Sugarman, P.J., Miller, K.G., Abdul, N.A., Aubry, M.-P., Edwards, L.E., Bukry, D., Esmeray, S., Feigenson, M.D., Graf, W., Harris, A.D., Martin, P.J., McLaughlin, P.P., Mizintseva, S.F., Monteverde, D.H., Montone, L.M., Olsson, R.K., Uptegrove, J., Wahyudi, H., Wang, H., and Zulfitriadi, 2011. Double Trouble site. In Miller, Sugarman, Browning, et al., Proceedings of the Ocean Drilling Program, 174AX (Suppl.), College Station, TX (Ocean Drilling Program), 1-63. http://dx.doi.org/10.2973/odp.proc.ir.174AXS.110.2011

Cook, G.H., 1868. The geology of New Jersey. New Jersey Geological Survey, 263-242.

Cramer, B.S., Aubry, M.-P., Miller, K.G., Olsson, R.K., Wright, J.D., and Kent, D.V., 1999. An exceptional chronologic, isotopic, and clay mineralogic record of the latest Paleocene thermal maximum. Bass River, N.J., ODP 174AX. Bulletin De La Societe Geologique De France, 170:883-897.

Darton, N.H., 1948. The Marlboro clay [Maryland-Virginia]. Economic Geology, 43(2):154-155. http://dx.doi.org/10.2113/gsecongeo.43.2.154

Edwards, L.E., 1996. Graphic correlation of the Marlboro clay and Nanjemoy Formation (uppermost Paleocene and lower Eocene) of Virginia and Maryland. In Jansonius, J., and McGregor, D.C. (Eds.), Palynology: Principles and Applications, Vol. 3: Salt Lake City (American Association of Stratigraphic Palynologists Foundation), 989-999.

Farley, K.A., and Eltgroth, S.F., 2003. An alternative age model for the Paleocene/Eocene Thermal Maximum using extraterrestrial ${ }^{3} \mathrm{He}$. Earth and Planetary Science Letters, 208(3-4):135-148. http://dx.doi.org/10.1016/S0012-821X(03)00017-7

Gibbs, S.J., Bown, P.R., Sessa, J.A., Bralower, T.J., and Wilson, P.A., 2006 a. Nannoplankton extinction and origination across the Paleocene-Eocene Thermal Maximum. Science, 314(5806):1770-1773. http://dx.doi.org/10.1126/science.1133902

Gibbs, S.J., Bralower, T.J., Bown, P.R., Zachos, J.C., and Bybell, L.M., 2006 b. Shelf and open-ocean calcareous phytoplankton assemblages across the Paleocene-Eocene Thermal Maximum: implications for global productivity gradients. Geology, 34(4):233-236. http://dx.doi.org/10.1130/G22381.1

Gibson, T.G., Bybell, L.M., and Mason, D.B., 2000. Stratigraphic and climatic implications of clay mineral changes around the Paleocene/Eocene boundary of the northeastern US margin. Sedimentary Geology, 134(12):65-92. http://dx.doi.org/10.1016/S0037-0738(00)00014-2

Gibson, T.G., Bybell, L.M., and Owens, J.P., 1993. Latest Paleocene lithologic and biotic events in neritic deposits of southwestern New Jersey. Paleoceanography, 8(4):495-514. http://dx.doi.org/10.1029/93PA01367

Glaser, J.D., 1971. Geology and mineral resources of southern Maryland. Maryland Geological Survey, 15. http://www.mgs.md.gov/publications/report_pages/RI_15.html

Gradstein, F.M., Ogg, J.G., and Smith, A. (Eds.), 2004. A Geologic Time Scale 2004: Cambridge, UK (Cambridge Univ. Press). https://doi.org/10.2277/0521786738

Gradstein, F.M., Ogg, J.G., Schmitz, M.D., and Ogg, G.M. (Eds.)., 2012. The Geological Time Scale 2012: Amsterdam (Elsevier).

Harris, A.D., Miller, K.G., Browning, J.V., Sugarman, P.J., Olsson, R.K., Cramer, B.S., and Wright, J.D., 2010. Integrated stratigraphic studies of Paleocene-lowermost Eocene sequences, New Jersey coastal plain: evidence for glacioeustatic control. Paleoceanography, 25(3):PA3211. http://dx.doi.org/10.1029/2009PA001800

Hart, S.E., and Brooks, C., 1974. Clinopyroxene-matrix partitioning of $\mathrm{K}, \mathrm{Rb}$, Cs, Sr, and Ba. Geochimica et Cosmochimica Acta, 38(12):1799-1806. http://dx.doi.org/10.1016/0016-7037(74)90163-X

John, C.M., Bohaty, S.M., Zachos, J.C., Sluijs, A., Gibbs, S., Brinkhuis, H., and Bralower, T.J., 2008. North American continental margin records of the Paleocene-Eocene Thermal Maximum: implications for global carbon and hydrological cycling. Paleoceanography, 23(2). http://dx.doi.org/10.1029/2007PA001465

Katz, M.E., Pak, D.K., Dickens, G.R., and Miller, K.G., 1999. The source and fate of massive carbon input during the latest Paleocene thermal maxi- mum. Science, 286(5444):1531-1533.

http://dx.doi.org/10.1126/science.286.5444.1531

Kennett, J.P., and Stott, L.D., 1991. Abrupt deep-sea warming, paleoceanographic changes and benthic extinctions at the end of the Palaeocene. Nature, 353(6341):225-229. http://dx.doi.org/10.1038/353225a0

Kopp, R.E., Schumann, D., Raub, T.D., Powars, D.S., Godfrey, L.V., SwansonHysell, N.L., Maloof, A.C., and Vali, H., 2009. An Appalachian Amazon? Magnetofossil evidence for the development of a tropical river-like system in the mid-Atlantic United States during the Paleocene-Eocene Thermal Maximum. Paleoceanography, 24(4):PA4211. http://dx.doi.org/10.1029/2009PA001783

Lippert, P.C., and Zachos, J.C., 2007. A biogenic origin for anomalous finegrained magnetic material at the Paleocene-Eocene boundary at Wilson Lake, New Jersey. Paleoceanography, 22(4):PA4104. http://dx.doi.org/10.1029/2007PA001471

Lombardi, C., 2013. The Marlboro Formation [M.S. thesis]. Rutgers University, New Jersey. https://rucore.libraries.rutgers.edu/rutgers-lib/42420/

Makarova, M., Wright, J.D., Miller, K.G., Babila, T.L., Rosenthal, Y., and Park, J.I., 2017. Hydrographic and ecologic implications of foraminiferal stable isotopic response across the U.S. mid-Atlantic continental shelf during the Paleocene-Eocene Thermal Maximum. Paleoceanography, 32(1):5673. https:/doi.org/10.1002/2016PA002985

Martini, E., 1971. Standard Tertiary and Quaternary calcareous nannoplankton zonation. In Farinacci, A. (Ed.), Proceeding of the Second Planktonic Conference Roma 1970: Rome (Edizioni Tecnoscienza), 2:739-785.

Martini, E., and Müller, C., 1986. Current Tertiary and Quaternary calcareous nannoplankton stratigraphy and correlations. Newsletters on Stratigraphy, 16(2):99-112. http://dx.doi.org/10.1127/nos/16/1986/99

McArthur, J.M., Howarth, R.J., and Bailey, T.R., 2001. Strontium isotope stratigraphy: LOWESS version 3: best fit to the marine Sr-isotope curve for 0-509 Ma and accompanying look-up table for deriving numerical age. Journal of Geology, 109(2):155-170. http://dx.doi.org/10.1086/319243

Miller, K.G., Browning, J.V., Liu, C., Sugarman, P., Kent, D.V., Van Fossen, M., Queen, D., Goss, M., Gwynn, D., Mullikin, L., Feigenson, M.D., Aubry, M.-P., and Burckle, L.D., 1994a. Atlantic City site report. In Miller, K.G., et al., Proceedings of the Ocean Drilling Program, Initial Reports, 150X: College Station, TX (Ocean Drilling Program), 35-55. http://dx.doi.org/10.2973/odp.proc.ir.150X.112.1994

Miller, K.G., Liu, C., Browning, J.V., Pekar, S.F., Sugarman, P.J., Van Fossen, M.C., Mullikin, L., Queen, D., Feigenson, M.D., Aubry, M.-P., Burckle, L.D., Powars, D., and Heibel, T., 1996a. Cape May site report. Proceedings of the Ocean Drilling Program, Initial Reports, 150X (Suppl.): College Station, TX (Ocean Drilling Program), 5-28. http://dx.doi.org/10.2973/odp.proc.ir.150XS.014.1996

Miller, K.G., McLaughlin, P.P., Browning, J.V., Benson, R.N., Sugarman, P.J., Hernandez, J., Ramsey, K.W., Baxter, S.J., Feigenson, M.D., Aubry, M.-P., Monteverde, D.H., Cramer, B.S., Katz, M.E., McKenna, T.E., Strohmeier, S.A., Pekar, S.F., Uptegrove, J., Cobbs, G., Cobbs, G., III, and Curtin, S.E., 2003. Bethany Beach site. In Miller, K.G., Sugarman, P.J., Browning, J.V., et al., Proceedings of the Ocean Drilling Program, Initial Reports, 174AX (Suppl.): College Station, TX (Ocean Drilling Program), 1-84. http://dx.doi.org/10.2973/odp.proc.ir.174AXS.103.2003

Miller, K.G., and Mountain, G.S., 1994. Global sea-level change and the New Jersey margin. In Mountain, G.S., Miller, K.G., Blum, P., et al., Proceedings of the Ocean Drilling Program, Initial Reports, 150: College Station, TX (Ocean Drilling Program), 11-20. http://dx.doi.org/10.2973/odp.proc.ir.150.102.1994

Miller, K.G., Mountain, G.S., Browning, J.V., Kominz, M., Sugarman, P.J., Christie-Blick, N., Katz, M.E., and Wright, J.D., 1998a. Cenozoic global sea level, sequences, and the New Jersey transect: results from coastal plain and continental slope drilling. Reviews Of Geophysics, 36(4):569602. http://dx.doi.org/10.1029/98RG01624 
Miller, K.G., Mountain, G.S., and Leg 150 Shipboard Party and Members of the New Jersey Coastal Plain Drilling Project, 1996b. Drilling and dating New Jersey Oligocene-Miocene sequences: ice volume, global sea level, and Exxon records. Science, 271(5252):1092-1095. http://dx.doi.org/10.1126/science.271.5252.1092

Miller, K.G., Rufolo, S., Sugarman, P.J., Pekar, S.F., Browning, J.V., and Gwynn, D.W., 1997. Early to middle Miocene sequences, systems tracts, and benthic foraminiferal biofacies, New Jersey coastal plain. In Miller, K.G., and Snyder, S.W. (Eds.), Proceedings of the Ocean Drilling Program, Scientific Results, 150X: College Station, TX (Ocean Drilling Program), 169-186. http://dx.doi.org/10.2973/odp.proc.sr.150X.313.1997

Miller, K.G., Sherrell, R.M., Browning, J.V., Field, M.P., Gallagher, W., Olsson, R.K., Sugarman, P.J., Tuorto, S., and Wahyudi, H., 2010. Relationship between mass extinction and iridium across the Cretaceous-Paleogene boundary in New Jersey. Geology, 38(10):867-870. http://dx.doi.org/10.1130/G31135.1

Miller, K.G., and Snyder, S.W. (Eds.), 1997. Proceedings of the Ocean Drilling Program, Scientific Results, 150X: College Station, TX (Ocean Drilling Program). http://dx.doi.org/10.2973/odp.proc.sr.150X.1997

Miller, K.G., Sugarman, P., Van Fossen, M., Liu, C., Browning, J.V., Queen, D., Aubry, M.-P., Burckle, L.D., Goss, M., and Bukry, D., 1994b. Island Beach site report. In Miller, K.G., et al., Proceedings of the Ocean Drilling Program, Initial Reports, 150X: College Station, TX (Ocean Drilling Program), 5-33. http://dx.doi.org/10.2973/odp.proc.ir.150X.111.1994

Miller, K.G., Sugarman, P.J., Browning, J.V., Aubry, M.-P., Brenner, G.J., Cobbs, G., III, de Romero, L., Feigenson, M.D., Harris, A., Katz, M.E., Kulpecz, A., McLaughlin, P.P., Jr., Misintseva, S., Monteverde, D.H., Olsson, R.K., Patrick, L., Pekar, S.J., and Uptegrove, J., 2006. Sea Girt site. In Miller, K.G., Sugarman, P.J., Browning, J.V., et al., Proceedings of the Ocean Drilling Program, Initial Reports, 174AX (Suppl.): College Station, TX (Ocean Drilling Program), 1-104.

http://dx.doi.org/10.2973/odp.proc.ir.174AXS.107.2006

Miller, K.G., Sugarman, P.J., Browning, J.V., Cramer, B.S., Olsson, R.K., de Romero, L., Aubry, M.-P., Pekar, S.F., Georgescu, M.D., Metzger, K.T., Monteverde, D.H., Skinner, E.S., Uptegrove, J., Mullikin, L.G., Muller, F.L., Feigenson, M.D., Reilly, T.J., Brenner, G.J., and Queen, D., 1999. Ancora site. In Miller, K.G., Sugarman, P.J., Browning, J.V., et al., Proceedings of the Ocean Drilling Program, Initial Reports, 174AX (Suppl.): College Station, TX (Ocean Drilling Program), 1-65. http://dx.doi.org/10.2973/odp.proc.ir.174AXS.101.1999

Miller, K.G., Sugarman, P.J., Browning, J.V., Kominz, M.A., Olsson, R.K., Feigenson, M.D., and Hernandez, J.C., 2004. Upper Cretaceous sequences and sea-level history, New Jersey coastal plain. Geological Society of America Bulletin, 116(3):368-393. http://dx.doi.org/10.1130/B25279.1

Miller, K.G., Sugarman, P.J., Browning, J.V., Olsson, R.K., Pekar, S.F., Reilly, T.J., Cramer, B.S., Aubry, M.-P., Lawrence, R.P., Curran, J., Stewart, M., Metzger, J.M., Uptegrove, J., Bukry, D., Burckle, L.H., Wright, J.D., Feigenson, M.D., Brenner, G.J., and Dalton, R.F., 1998b. Bass River Site. In Miller, K.G., Sugarman, P.J., Browning, J.V., et al., Proceedings of the Ocean Drilling Program, Initial Reports, 174AX: College Station, TX (Ocean Drilling Program), 5-43.

http://dx.doi.org/10.2973/odp.proc.ir.174AX.101.1998

Miller, K.G., Sugarman, P.J., Browning, J.V., Pekar, S.F., Katz, M.E., Cramer, B.S., Monteverde, D., Uptegrove, J., McLaughlin, P.P., Jr., Baxter, S.J., Aubry, M.-P., Olsson, R.K., Van Sickel, B., Metzger, K., Feigenson, M.D., Tiffin, S., and McCarthy, F., 2001. Ocean View site. In Miller, K.G., Sugarman, P.J., Browning, J.V., et al., Proceedings of the Ocean Drilling Program, Initial Reports, 174AX (Suppl.): College Station, TX (Ocean Drilling Program), 1-72. http://dx.doi.org/10.2973/odp.proc.ir.174AXS.102.2001

Miller, K.G., and Wright, J.D., 2017. Success and failure in Cenozoic global correlations using golden spikes: a geochemical and magnetostratigraphic perspective. Episodes, 40(1):8-21. https:/doi.org/10.18814/epiiugs/2017/v40i1/017003

Murphy, B.H., Farley, K.A., and Zachos, J.C., 2010. An extraterrestrial ${ }^{3} \mathrm{He}-$ based timescale for the Paleocene-Eocene Thermal Maximum (PETM) from Walvis Ridge, IODP Site 1266. Geochimica et Cosmochimica Acta, 74(17):5098-5108. http://dx.doi.org/10.1016/j.gca.2010.03.039
New Jersey Division of Water Resources, 1990. Generalized stratigraphic table for New Jersey. Information Circular-New Jersey Geological Survey, 1.

Olsson, R.K., Miller, K.G., Browning, J.V., Habib, D., and Sugarman, P.J., 1997. Ejecta Layer at the Cretaceous-Tertiary boundary, Bass River, New Jersey (Ocean Drilling Program Leg 174AX). Geology, 25(8):759-762. http://dx.doi.org/10.1130/0091-7613(1997)025<0759:ELATCT>2.3. $\mathrm{CO} ; 2$

Olsson, R.K., Miller, K.G., Browning, J.V., Wright, J.D., and Cramer, B.S., 2002. Sequence stratigraphy and sea level change across the Cretaceous/Tertiary boundary on the New Jersey passive margin. In Koeberl, C., and MacLeod, K.G. (Eds.), Catastrophic Events and Mass Extinctions: Impacts and Beyond: Special Paper-Geological Society of America, 356:97-108. http://dx.doi.org/10.1130/0-8137-2356-6.97

Oslick, J.S., Miller, K.G., Feigenson, M.D., and Wright, J.D., 1994. OligoceneMiocene strontium isotopes: stratigraphic revisions and correlations to an inferred glacioeustatic record. Paleoceanography, 9(3):427-443. http://dx.doi.org/10.1029/94PA00249

Owens, J.P., Sugarman, P.J., Sohl, N.F., Parker, R., Houghton, H.F., Volkert, R.A., Drake, A.A., and Orndorff, R.C., 1995. Geologic map of New Jersey: central sheet. Open-File Report-United States Geological Survey, 95-253.

Owens, J.P., Sugarman, P.J., Sohl, N.F., Parker, R.A., Houghton, H.F., Volkert, R.A., Drake, A.A., Jr., and Orndorff, R.C., 1999. Bedrock geologic map of central and southern New Jersey, 1:100,000. Miscellaneous Investigations Series Map, I-2540-B.

Pearson, P.N., and Nicholas, C.J., 2014. Layering in the Paleocene/Eocene boundary of the Millville core is drilling disturbance. Proceedings of the National Academy of Sciences of the United States of America, 111(12):E1064-E1065. http://dx.doi.org/10.1073/pnas.1322077111

Pearson, P.N., Olsson, R.K., Huber, B.T., Hemleben, C., and Berggren, W.A. (Eds.), 2006. Atlas of Eocene Planktonic Foraminifera. Special Publication-Cushman Foundation for Foraminiferal Research, 41.

Pearson, P.N., and Thomas, E., 2015. Drilling disturbance and constraints on the onset of the Paleocene-Eocene boundary carbon isotope excursion in New Jersey. Climate of the Past, 11:95-104. http://dx.doi.org/10.5194/cp-11-95-2015

Posamentier, H.W., Jervey, M.T., and Vail, P.R., 1988. Eustatic controls on clastic deposition, I. Conceptual framework. In Wilgus, C.K., Hastings, B.S., Posamentier, H., Van Wagoner, J., Ross, C.A., and Kendall, C.G.St.C. (Eds.), Sea-Level Changes: An Integrated Approach. Special PublicationSociety of Economic Paleontologists and Mineralogists, 42:109-124. http://dx.doi.org/10.2110/pec.88.01.0109

Powars, D.S., and Edwards, L.E., 2015. Paleocene-Eocene Thermal Maximum lithofacies across the mid-Atlantic coastal plain: sedimentological analysis of 100's of stacked turbidite packages. Geological Society of America, Abstracts with Programs, 47(7):630. https://gsa.confex.com/gsa/2015AM/webprogram/Paper270554.html

Röhl, U., Bralower, T.J., Norris, R.D., and Wefer, G., 2000. New chronology for the late Paleocene thermal maximum and its environmental implications. Geology, 28(10):927-930. http://dx.doi.org/10.1130/00917613(2000) $28<927$ :NCFTLP $>2.0 . C O ; 2$

Röhl, U., Westerhold, T., Bralower, T.J., and Zachos, J.C., 2007. On the duration of the Paleocene-Eocene Thermal Maximum (PETM). Geochemistry, Geophysics, Geosystems, 8:Q12002. http://dx.doi.org/10.1029/2007GC001784

Savrda, C.E., Browning, J.V., Krawinkel, H., and Hesselbo, S.P., 2001. Firmground ichnofabrics in deep-water sequence stratigraphy, Tertiary clinoform-toe deposits, New Jersey slope. Palaios, 16(3):294-305. http://dx.doi.org/10.2307/3515606

Schumann, D., Raub, T.D., Kopp, R.E., Guerquin-Kern, J.-L., Wue, T.-D., Rouiller, I., Smirnov, A.V., Sears, S.K., Lücken, U., Tikoo, S.M., Hesse, R., Kirschvink, J.L., and Vali, H., 2008. Gigantism in unique biogenic magnetite at the Paleocene-Eocene Thermal Maximum. Proceedings of the National Academy of Sciences of the United States of America, 105(46):17648-17653. http://dx.doi.org/ 10.1073/pnas.0803634105

Sluijs, A., and Brinkhuis, H., 2009. A dynamic climate and ecosystem state during the Paleocene-Eocene Thermal Maximum: inferences from dino- 
flagellate cyst assemblages on the New Jersey shelf. Biogeosciences, 6(8):1755-1781. http://dx.doi.org/10.5194/bg-6-1755-2009

Sluijs, A., Brinkhuis, H., Crouch, E.M., John, C.M., Handley, L., Munsterman, D., Bohaty, S.M., Zachos, J.C., Reichart, G.-J., Schouten, S., Pancost, R.D., Sinninghe Damsté, J.S., Welters, N.L.D., Lotter, A.F., and Dickens, G.R., 2008. Eustatic variations during the Paleocene-Eocene greenhouse world. Paleoceanography, 23(4):PA4216. http://dx.doi.org/10.1029/2008PA001615

Sluijs, A., Brinkhuis, H., Schouten, S., Bohaty, S.M., John, C.M., Zachos, J.C., Reichart, G.-J., Sinninghe Damsté, J.S., Crouch, E.M., and Dickens, G.R., 2007. Environmental precursors to rapid light carbon injection at the Palaeocene/Eocene boundary. Nature, 450(7173):1218-1221. http://dx.doi.org/10.1038/nature06400

Stassen, P., Thomas, E., and Speijer, R.P., 2012. Integrated stratigraphy of the Paleocene-Eocene Thermal Maximum in the New Jersey coastal plain: toward understanding the effects of global warming in a shelf environment. Paleoceanography, 27(4). http://dx.doi.org/10.1029/2012PA002323

Stassen, P., Thomas, E., and Speijer, R.P., 2015. Paleocene-Eocene Thermal Maximum environmental change in the New Jersey Coastal Plain: benthic foraminiferal biotic events. Marine Micropaleontology, 115:1-23. https://doi.org/10.1016/j.marmicro.2014.12.001

Sugarman, P.J., Miller, K.G., Browning, J.V., Aubry, M.-P., Brenner, G.J., Bukry, D., Butari, B., Feigenson, M.D., Kulpecz, A.A., McLaughlin, P.P., Jr., Mizintseva, S., Monteverde, D.H., Olsson, R.K., Pusz, A.E., Tomlinson, J., Uptegrove, J., Rankin, H., Velez, C.C., 2010. Medford site. In Miller, K.G., Sugarman, P.J., Browning, J.V., et al., Proceedings of the Ocean Drilling Program, Initial reports, Volume 174AX (Suppl.): College Station, TX (Ocean Drilling Program), 1-93. http://dx.doi.org/10.2973/odp.proc.ir.174AXS.109.2010

Sugarman, P.J., Miller, K.G., Browning, J.V., McLaughlin, P.P., Jr., Brenner, G.J., Buttari, B., Cramer, B.S., Harris, A., Hernandez, J., Katz, M.E., Lettini, B., Misintseva, S., Monteverde, D.H., Olsson, R.K., Patrick, L., Roman, E., Wojtko, M.J., Aubry, M.-P., Feigenson, M.D., Barron, J.A., Curtin, S., Cobbs, G., Cobbs, G., III, Bukry, D., and Huffman, B., 2005. Millville site. In Miller, K.G., Sugarman, P.J., Browning, J.V., et al., Proceedings of the Ocean Drilling Program, Initial Reports, 174AX (Suppl.): College Station, TX (Ocean Drilling Program), 1-94. http://dx.doi.org/10.2973/odp.proc.ir.174AXS.106.2005
Sugarman, P.J., Miller, K.G., Browning, J.V., Monteverde, D.H., Uptegrove, J., McLaughlin, P.P., Jr., Stanley, A.M., Wehmiller, J., Kulpecz, A., Harris, A., Pusz, A., Kahn, A., Friedman, A., Feigenson, M.D., Barron, J., and McCarthy, F.M.G., 2007. Cape May Zoo site. In Miller, K.G., Sugarman, P.J., Browning, J.V., et al., Proceedings of the Ocean Drilling Program, Initial Reports, 174AX (Suppl.): College Station, TX (Ocean Drilling Program), 1-66. http://dx.doi.org/10.2973/odp.proc.ir.174AXS.108.2007

Sugarman, P.J., Miller, K.G., Bukry, D., and Feigenson, M.D., 1995. Uppermost Campanian-Maestrichtian strontium isotopic, biostratigraphic, and sequence stratigraphic framework of the New Jersey coastal plain. Geological Society of America Bulletin, 107(1):19-37.

http://dx.doi.org/10.1130/0016-7606(1995)107<0019:UCM$\mathrm{SIB}>2.3 . \mathrm{CO} ; 2$

Sugarman, P.J., Miller, K.G., McLaughlin, P.P., Jr., Browning, J.V., Hernandez, J., Monteverde, D., Uptegrove, J., Baxter, S.J., McKenna, T.E., Andres, A.S., Benson, R.N., Ramsey, K.W., Keyser, T., Katz, M.E., Kahn, A., Friedman, A., Wojtko, M., Feigenson, M.D., Olsson, R.K., Brenner, G., Self-Trail, J.M., and Cobbs, G., III, 2004. Fort Mott site. In Miller, K.G., Sugarman, P.J., Browning, J.V., et al., Proceedings of the Ocean Drilling Program, Initial Reports, 174AX (Suppl.): College Station, TX (Ocean Drilling Program), 1-50. http://dx.doi.org/10.2973/odp.proc.ir.174AXS.105.2004

Sugarman, P.J., Miller, K.G., Owens, J.P., and Feigenson, M.D., 1993. Strontium-isotope and sequence stratigraphy of the Miocene Kirkwood Formation, southern New Jersey. Geological Society of America Bulletin, 105(4):423-436.

http://dx.doi.org/10.1130/0016-7606(1993)105<0423:SIASSO > 2.3.C O;2

Wright, J.D., and Schaller, M.F., 2013. Evidence for a rapid release of carbon at the Paleocene-Eocene Thermal Maximum. Proceeding of the National Academy of Sciences of the United States of America, 110(40):1590815913. http://dx.doi.org/10.1073/pnas.1309188110

Zachos, J.C., Schouten, S., Bohaty, S., Quattlebaum, T., Sluijs, A., Brinkhuis, H., Gibbs, S.J., and Bralower, T.J., 2006. Extreme warming of mid-latitude coastal ocean during the Paleocene-Eocene Thermal Maximum: inferences from TEX86 and isotope data. Geology, 34(9):737-740. http://dx.doi.org/10.1130/G22522.1 
Figure F1. Location map showing the Wilson Lake Hole B site (red star) and existing Deep Sea Drilling Project (DSDP), Atlantic Margin Coring Project (AMCOR), ODP, and Integrated Ocean Drilling Program (IODP) coreholes analyzed as a part of the New Jersey (NJ)/Mid-Atlantic (MAT) sea level transect. Also shown are multichannel seismic data from Ewing (EW9009), Oceanus (Oc270), and Cape Hatteras (Ch0698) cruises. MN = Monmouth County, OC = Ocean County, BU = Burlington County, CD = Camden County, GL = Gloucester County, AT = Atlantic County, SA = Salem County, CU = Cumberland County, CM = Cape May County.

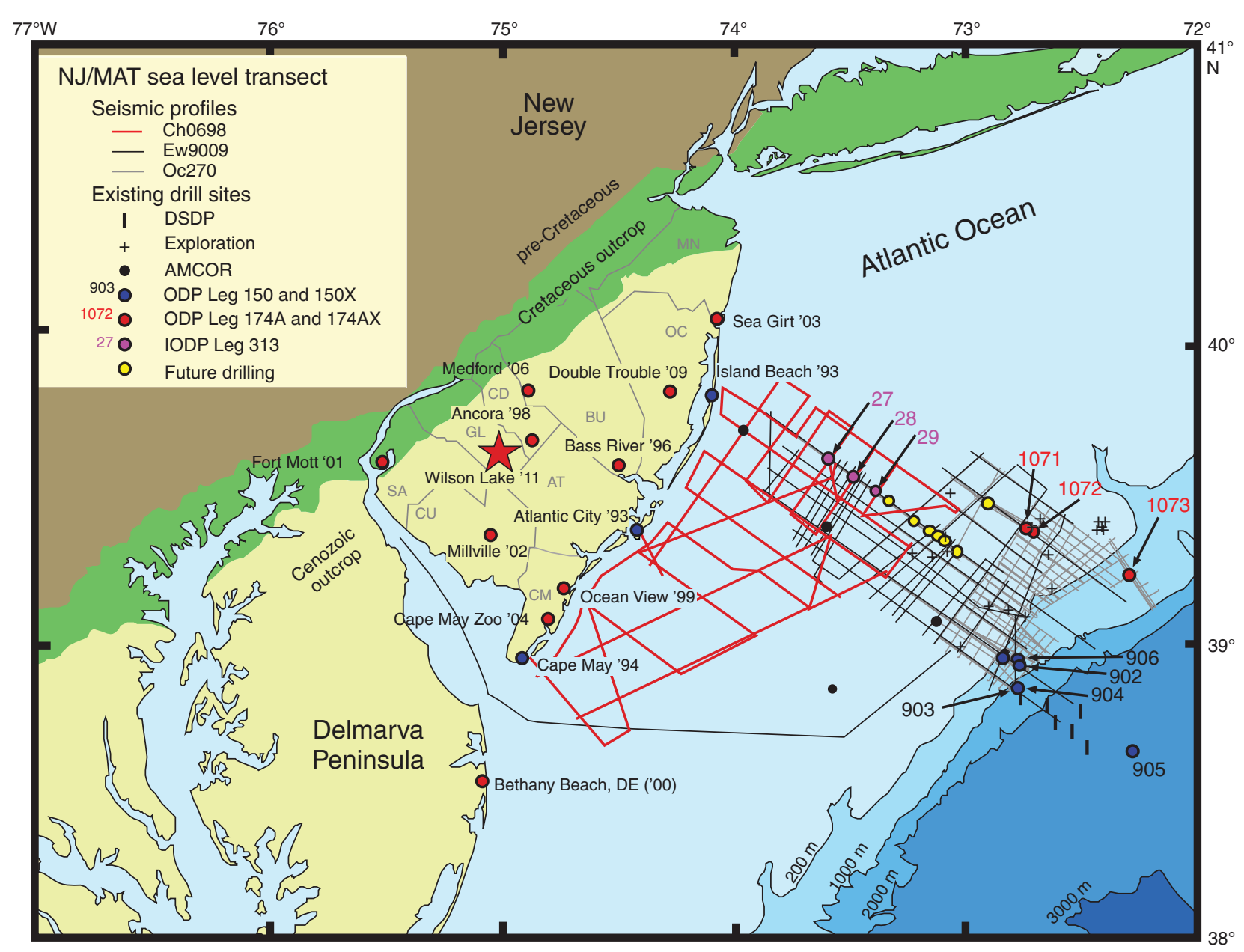


Figure F2. Gamma ray logs from Wilson Lake Holes A (red) and B (blue) to common depth scale. cps = counts per second. Nanno. = nannofossil zone. NP Zones are from Martini (1971) and Martini and Müller (1986).

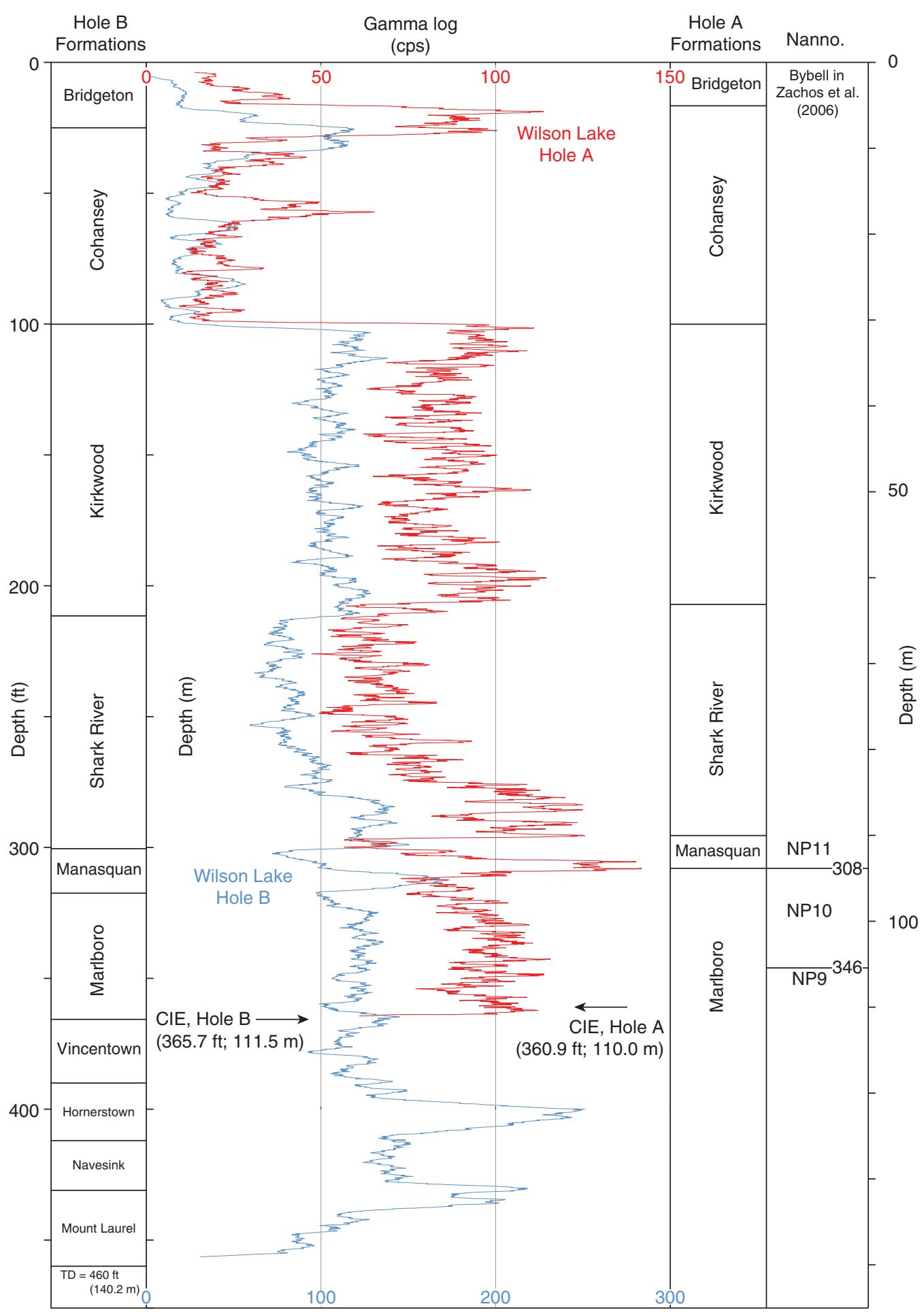


Figure F3. A. Summary stratigraphic section for the Bridgeton and Cohansey Formations (?uppermost middle to upper Miocene) in Wilson Lake Hole B, with core recovery, lithology, gamma ray and resistivity log signatures, and environments (Env.). (Continued on next page.)

\section{A}

$\begin{aligned} & \text { Depth Recovery Lithology } \\ & (\mathrm{ft})(\mathrm{m})\end{aligned}$
$\begin{aligned} & \text { Gamma log } \\ & \text { (cps) }\end{aligned}$

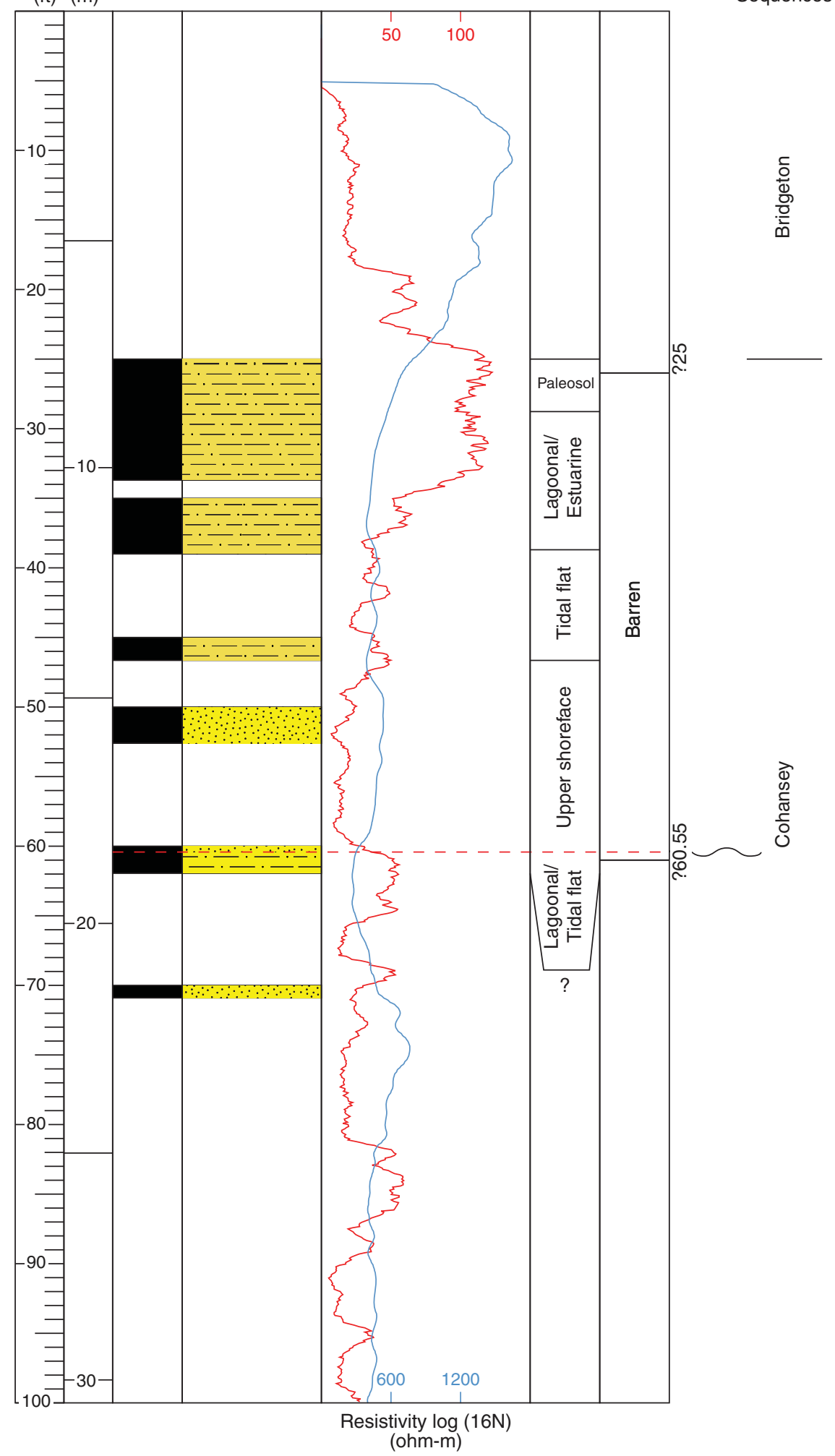


Figure F3 (continued). B. Legend of lithology symbols and abbreviations used on summary stratigraphic sections.

B

Cumulative percent

Lithology columns

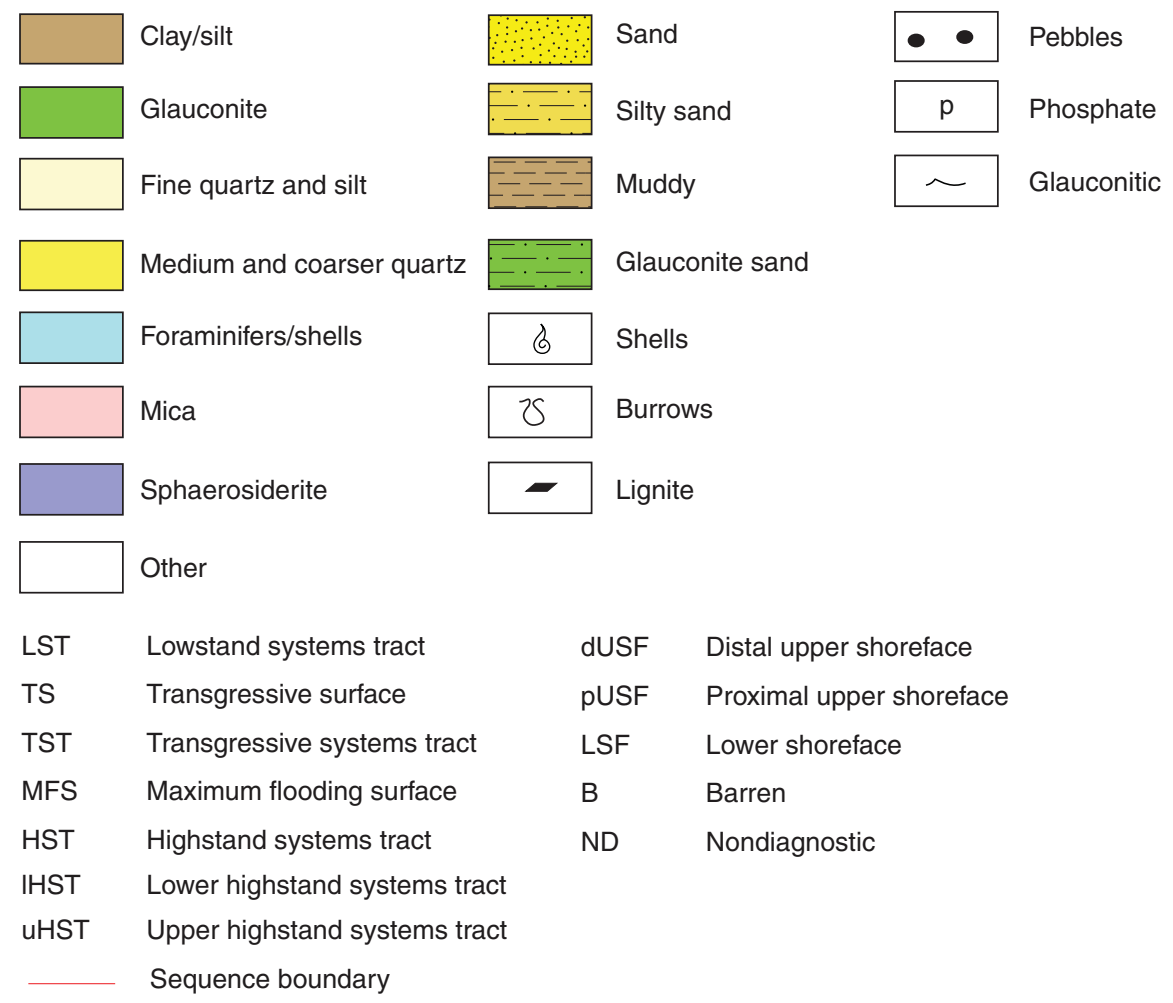


Figure F4. Summary stratigraphic section for the Kirkwood Formation (?lower to middle Miocene) in Wilson Lake Hole B, with core recovery, lithology, gamma ray and resistivity log signatures, age, and environments. Syst. = systems tract. SOT = shoreface-offshore transition, RI = riverine-influenced. Kw1a and Kw1b sequences are defined by Sugarman et al. (1993). Kw0 sequence is defined by Miller et al. (1997). See Figure F3B for legend.

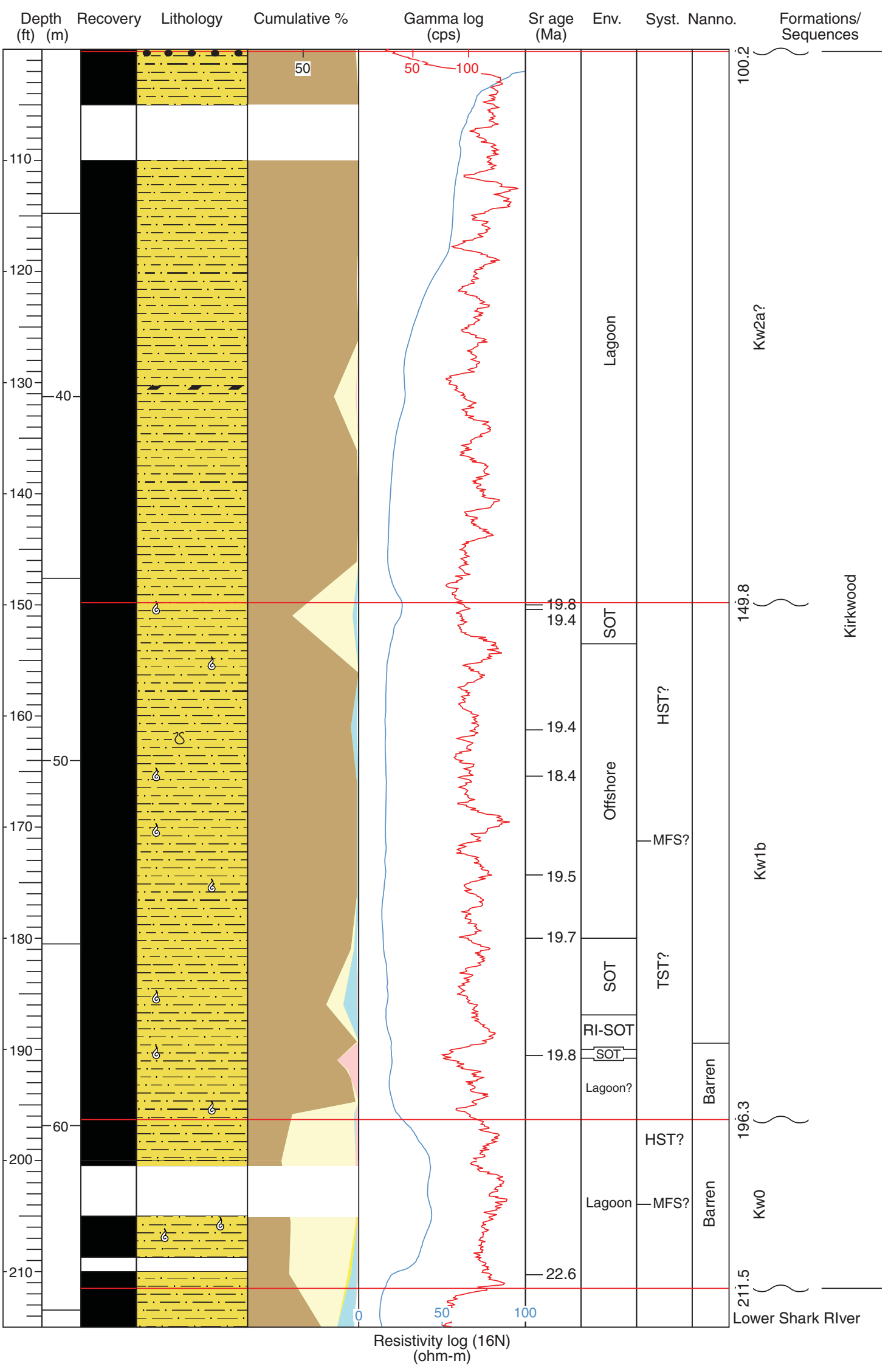


Figure F5. Summary stratigraphic section for the Deal Member (Mbr.) of the Shark River Formation (upper middle Eocene) in Wilson Lake Hole B, with core recovery, lithology, gamma ray and resistivity log signatures, age, and environments. $\mathrm{Sr}=$ strontium age estimate $(\mathrm{Ma})$, Foram. = foraminifer zone. NP Zones are from Martini (1971) and Martini and Müller (1986). E Zones are from Berggren et al. (1995). Kw0 sequence is defined by Miller et al. (1997). Sequences E6 and E7 are defined by Browning et al. (1997). See Figure F3B for legend.

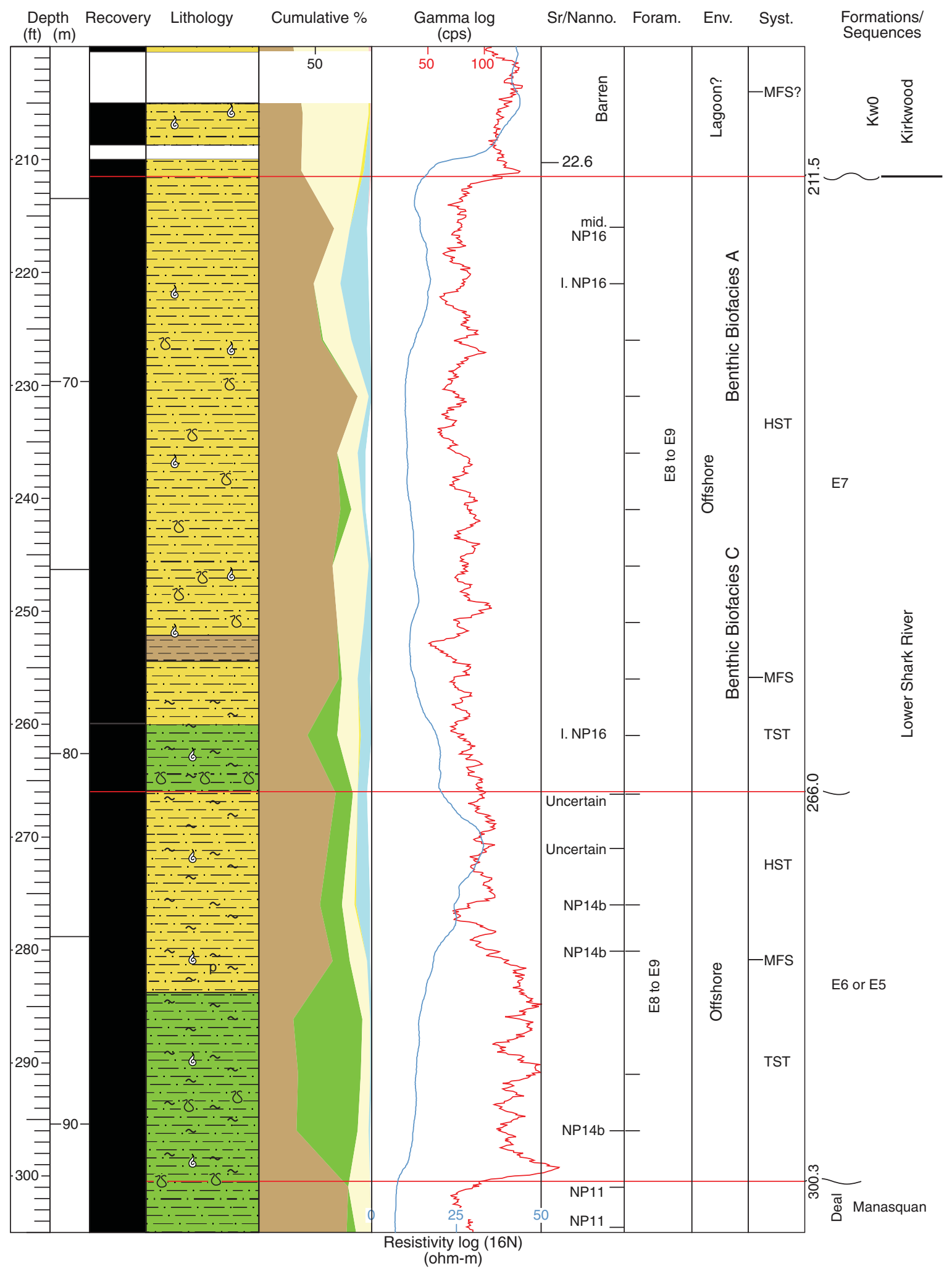


Figure F6. Summary stratigraphic section for the Manasquan (lower Eocene), Marlboro (lowermost Eocene), Vincentown (upper Paleocene), and Hornerstown (lower to lowermost upper Paleocene) formations in Wilson Lake Hole B, with core recovery, lithology, gamma ray and resistivity log signatures, $\delta^{13} \mathrm{C}$, and age. P Zones are from Berggren et al. (1995). NP Zones are from Martini (1971) and Martini and Müller (1986). Sequences E1 and E2 are defined by Browning et al. (1997). See Figure F3B for legend.

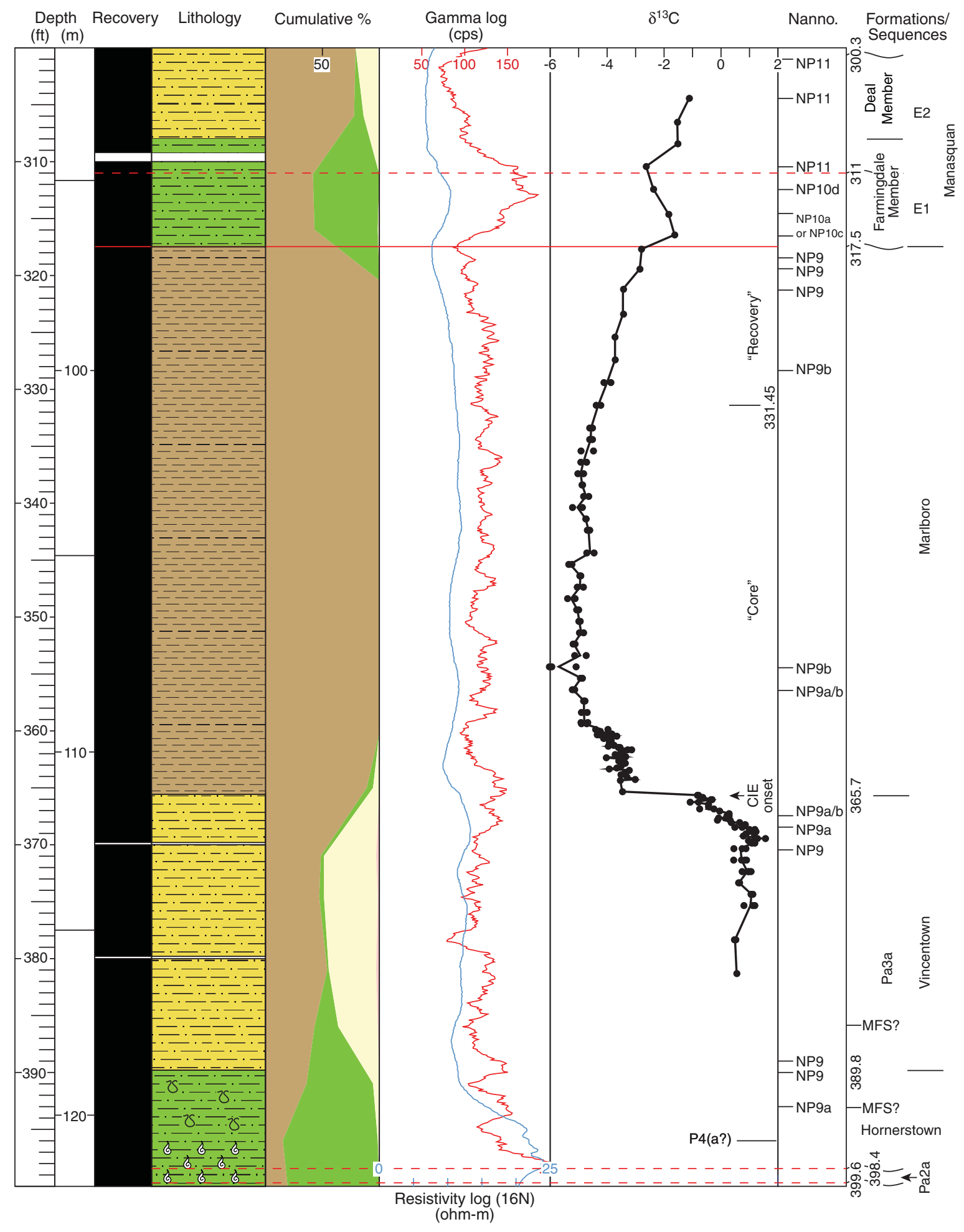


Figure F7. Summary stratigraphic section for the and Navesink (Maastrichtian) and Mount Laurel (Campanian) formations in Wilson Lake Hole B, with core recovery, lithology, gamma ray and resistivity log signatures, and age. P Zones are from Berggren et al. (1995). NP Zones are from Martini (1971) and Martini and Müller (1986). See Figure F3B for legend.

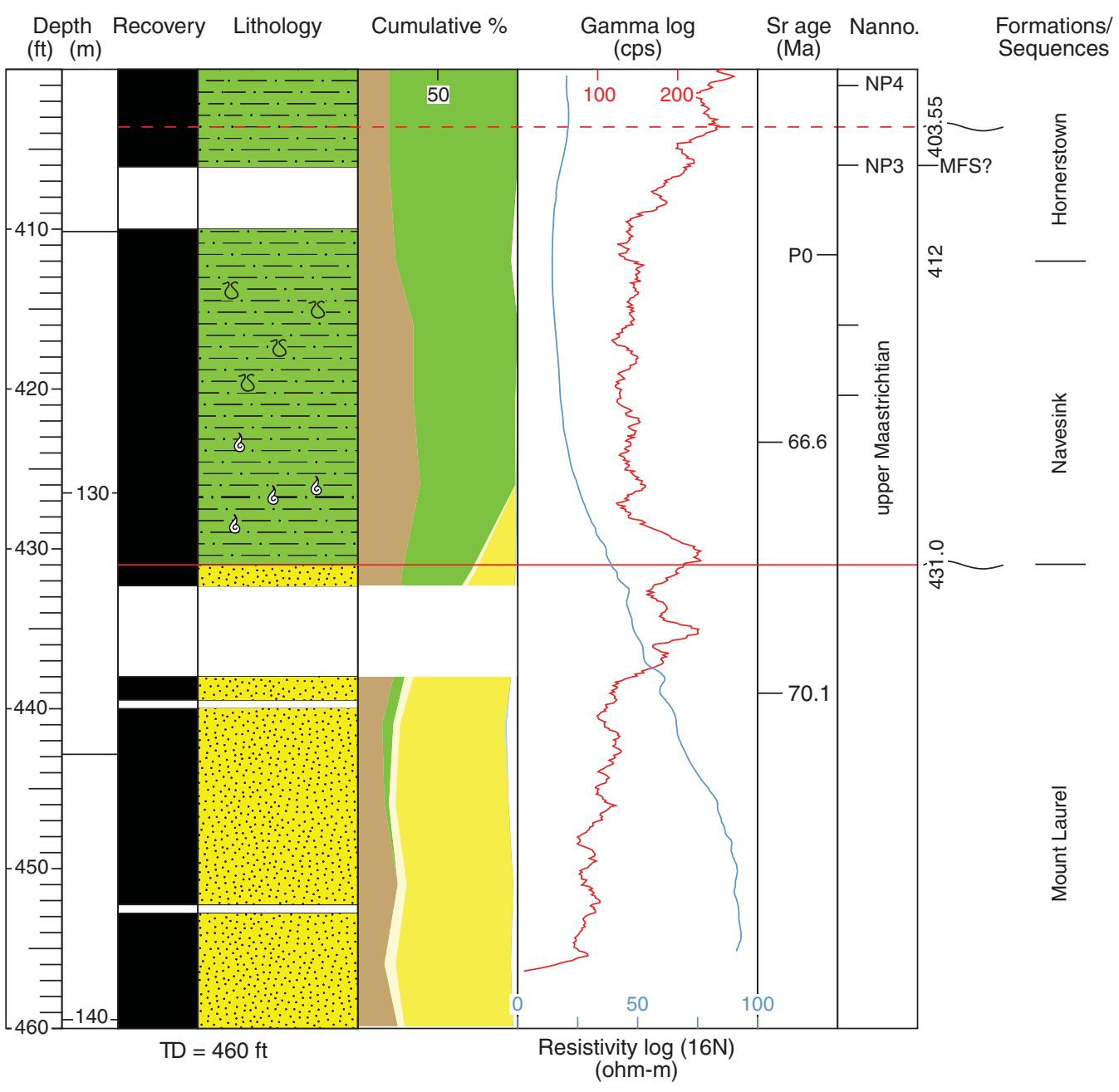


Figure F8. Carbon isotopes and percent carbonate data across the Vincentown/Marlboro Formation contact showing the CIE. Bulk $\delta^{13} \mathrm{C}$ and percent carbonate isotopic data from Wright and Schaller (2013). Grain size cumulative percent is from Lombardi (2013). Core photos have been stretched. Note black subvertical piece of lignite just below formational boundary.

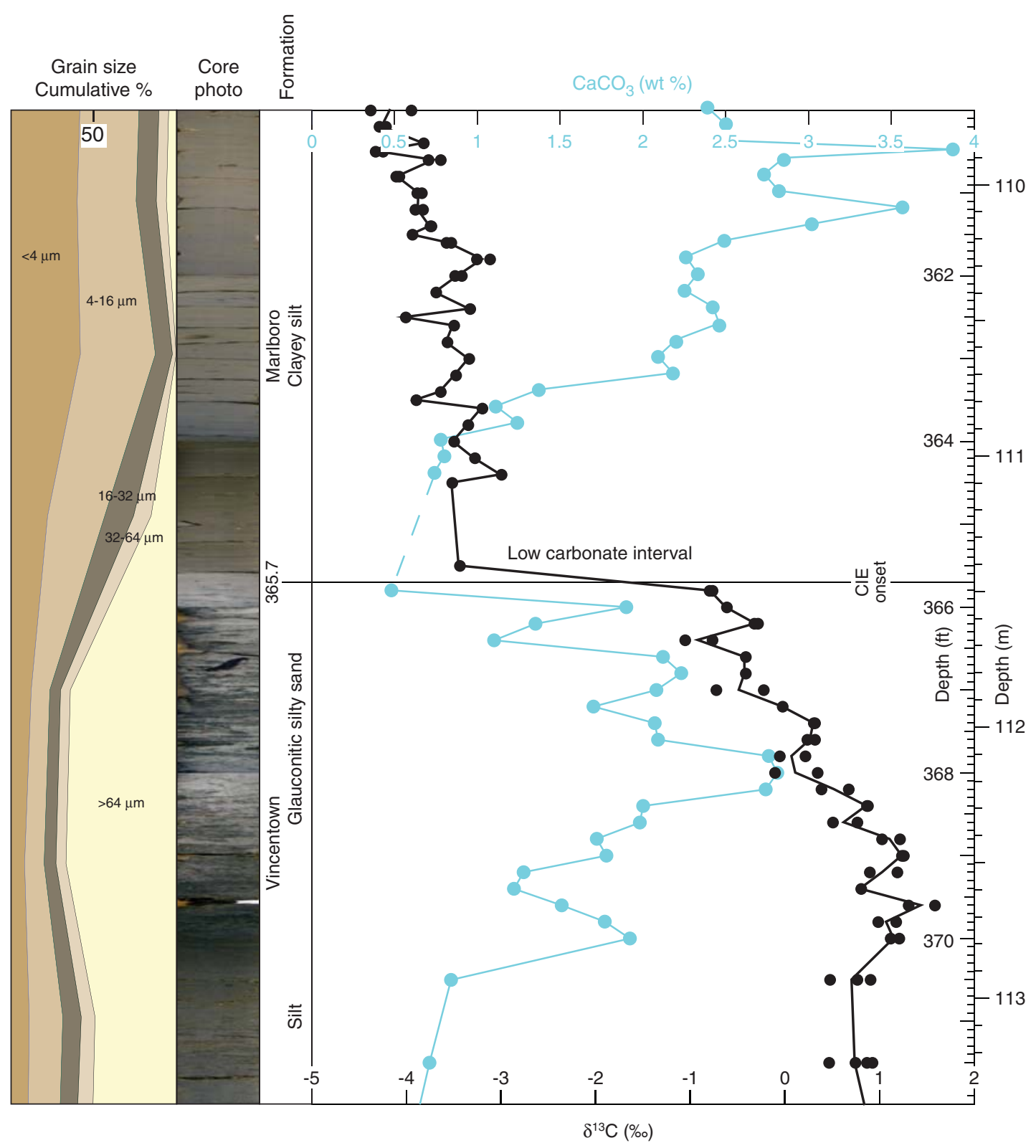


Figure F9. Age-depth plot for the latest Oligocene to middle Miocene. Errors are given in text. Red lines = sequence boundaries. Open circles were not included in the regression from 19.1 to $19.5 \mathrm{Ma}$. Sedimentation rate from above applied to Kw0 sequence.

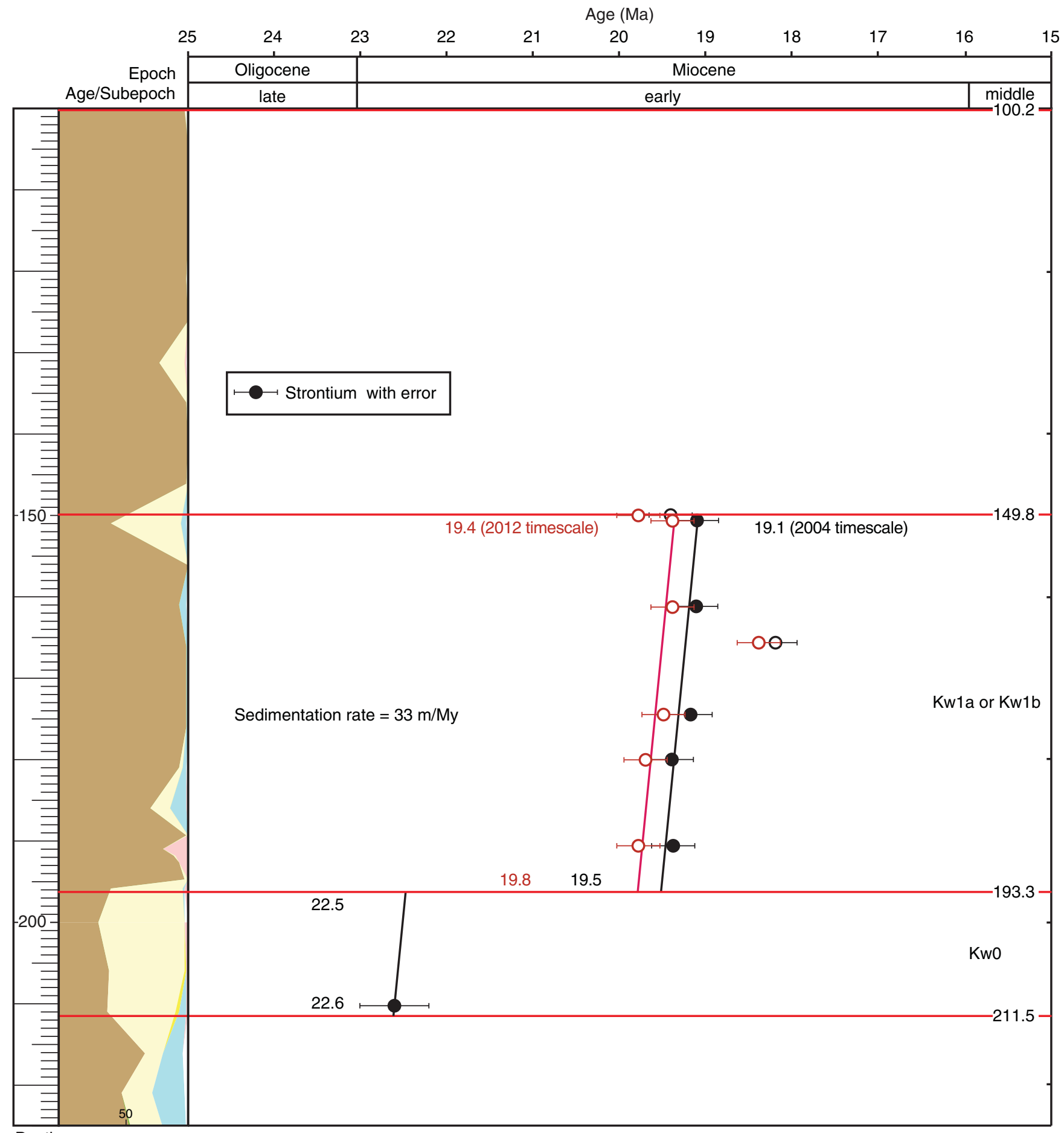

Depth Cumulative \%

(ft) 
Figure F10. Age-depth plot for the Late Cretaceous to middle Eocene. Errors are zonal durations. Red lines = sequence boundaries.

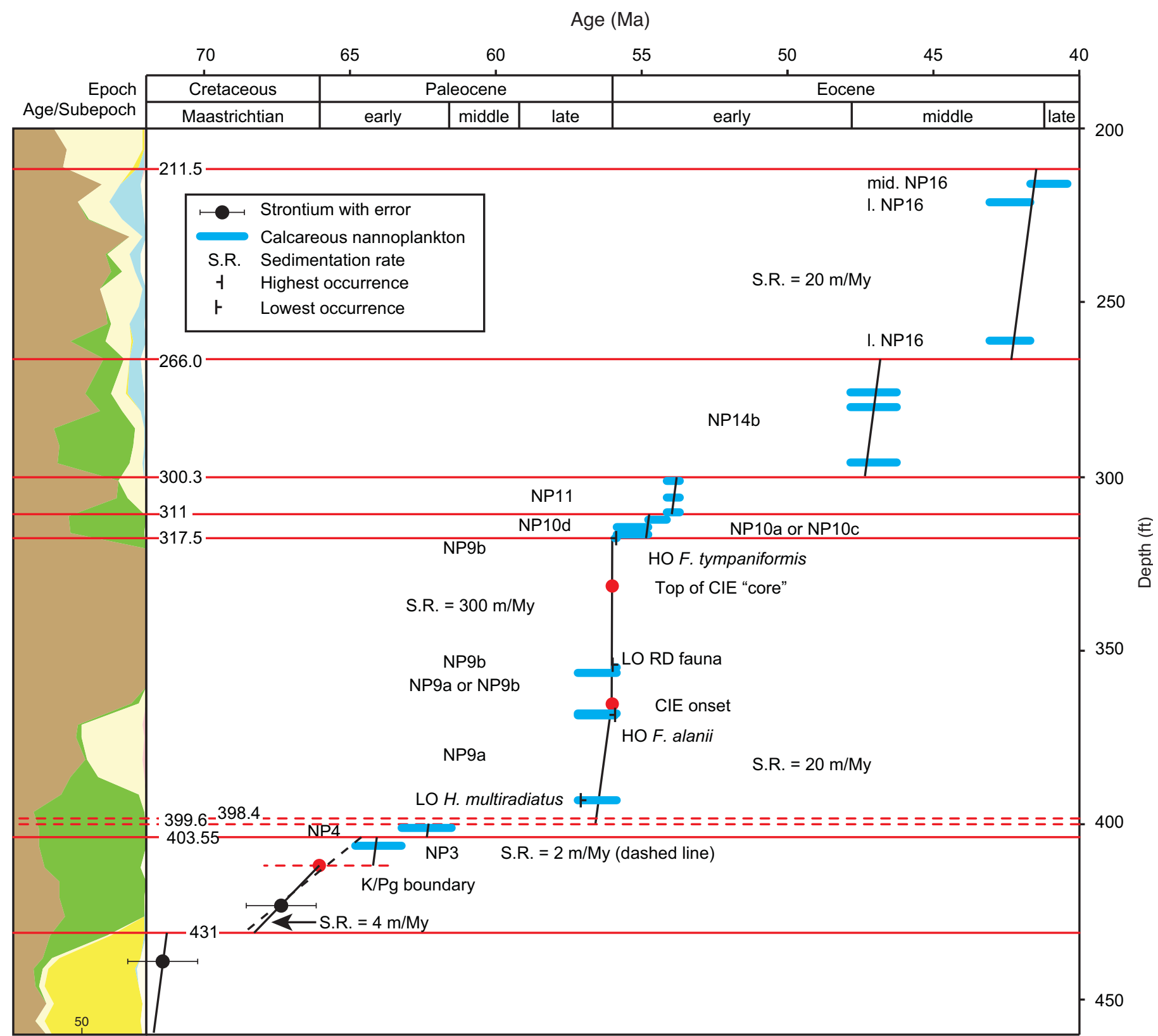

Cumulative \% 
Figure F11. Representative lithofacies from Wilson Lake Hole B: color banding ( 15 cm) from lagoonal facies in the Kirkwood Formation (122-124 ft; $37.2-27.8$ $\mathrm{m})$, color banding $(\sim 2 \mathrm{~cm})$ from lagoonal facies in the Kirkwood Formation (146-148 ft; 44.5-45.1 m), shoreface-offshore facies from the Kirkwood Formation (152-154 ft; 46.3-46.9 m), offshore facies from the Kirkwood Formation (154-156 ft; 46.9-47.5 m), sequence boundary at $211.5 \mathrm{ft}$ (64.5 m) separating the Kirkwood Formation Kw0 sequence above from the Shark River Formation Sequence E7 below (210-212 ft; 64.0-64.3 m).

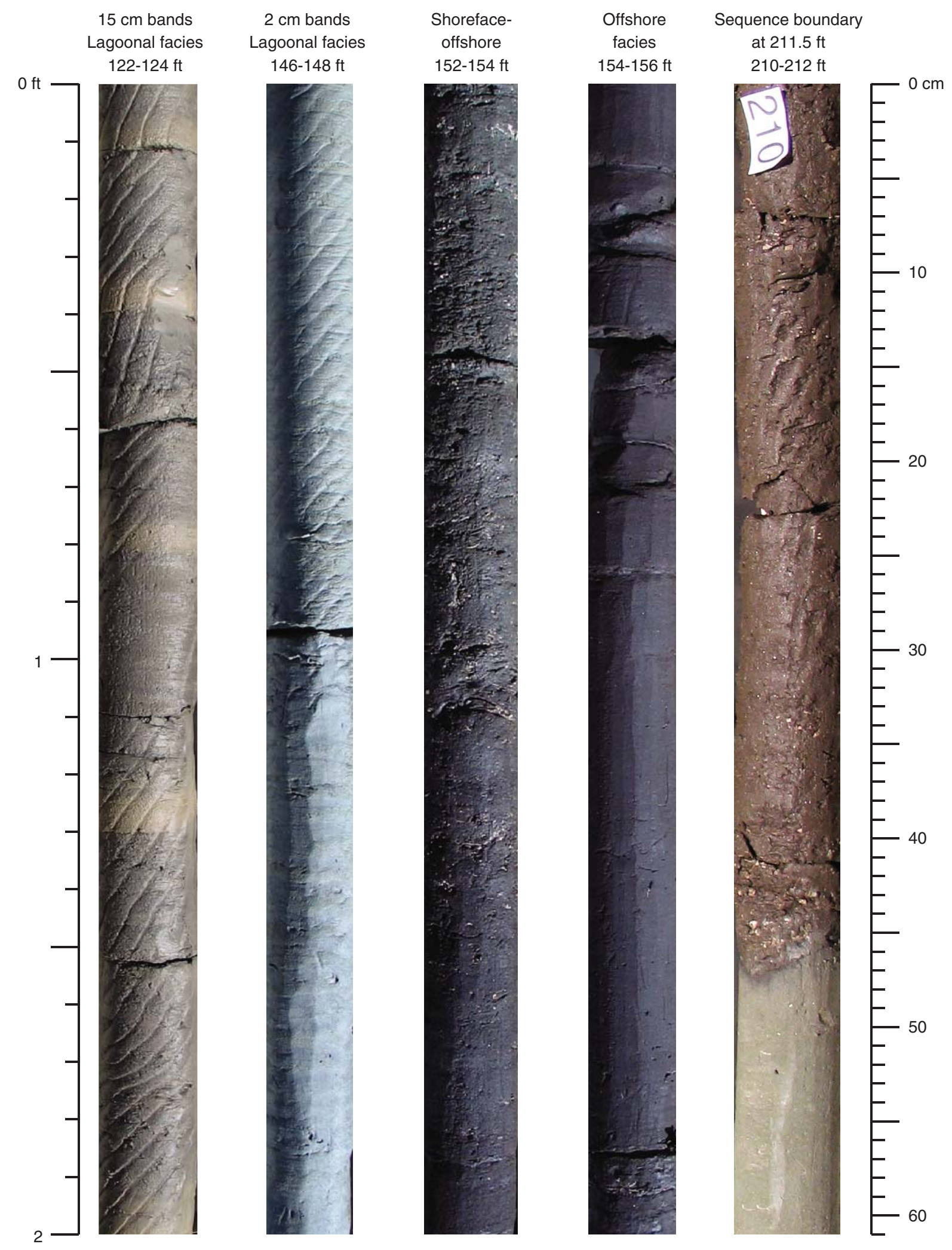


Figure F12. Representative lithofacies from Wilson Lake Hole B: Shark River Formation marls ( $235-237 \mathrm{ft} ; 71.6-72.2 \mathrm{~m}$ ), sequence boundary at $266.0 \mathrm{ft}$ ( $81.1 \mathrm{~m}$ ) separating Sequence E7 above from Sequence E5 or E6 below within the Shark River Formation (264.5-266.5 ft; 80.6-81.2 m), heavily burrowed glauconite clay in the Shark River Formation (282-284 ft; 86.0-86.6 m), Shark River/Manasquan Formation contact at $300.3 \mathrm{ft}(91.5 \mathrm{~m})(300-302 \mathrm{ft} ; 91.4-92.0 \mathrm{~m})$.

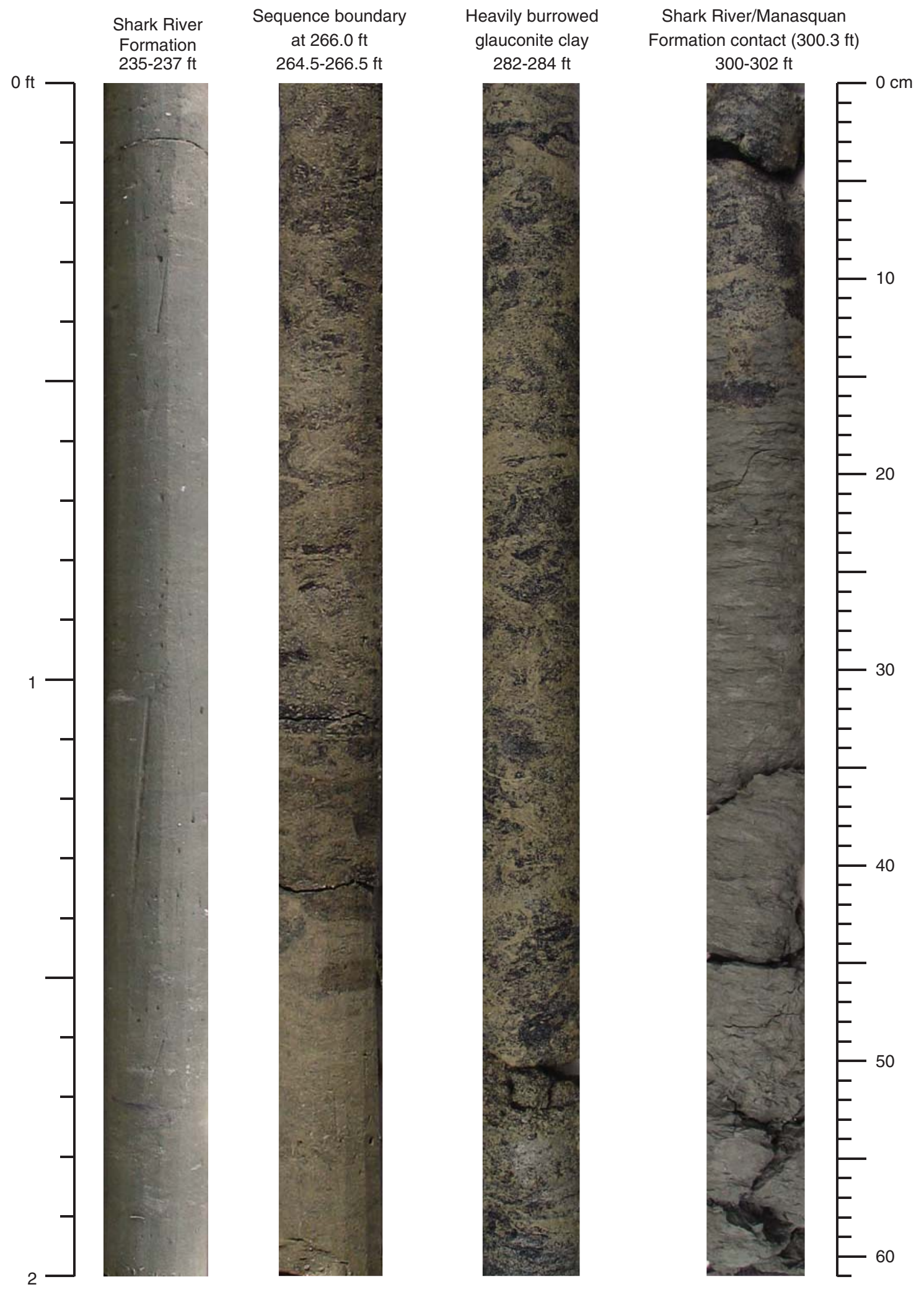


Figure F13. Representative lithofacies from Wilson Lake Hole B: Manasquan/Vincentown Formation contact at 317.5 ft (96.8 m) (316-318 ft; $96.3-96.9 \mathrm{~m})$, examples of laminations in the Marlboro Formation at (340-342 ft [103.6-104.2 m] and 352-354 ft [107.3-107.9 m]), Marlboro/Vincentown gradational contact (366-368 ft; $111.6-112.2 \mathrm{~m})$, enlargement of $5 \mathrm{~cm}$ subvertical piece of lignite at $366.6 \mathrm{ft}$ (111.7 m) (366.5-367 ft; $111.7-111.9 \mathrm{~m})$.

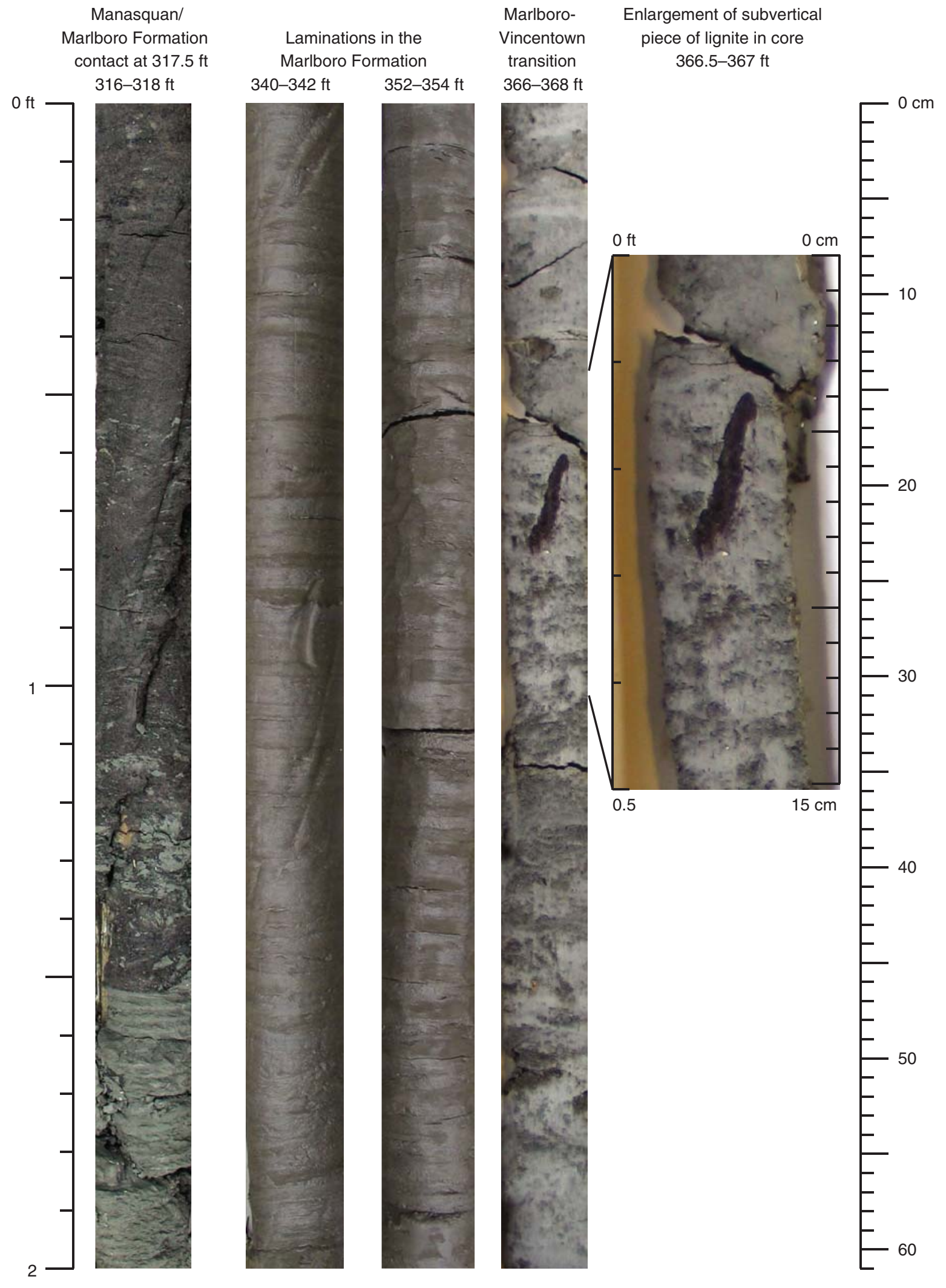


Figure F14. Representative lithofacies from the Wilson Lake Hole B: sequence boundary within the Hornerstown Formation at $398.4 \mathrm{ft}$ (121.4 m) (398-400 ft; 121.3-121.9 m), sequence boundary within the Hornerstown Formation at $403.55 \mathrm{ft}(123.0 \mathrm{~m})(402-404 \mathrm{ft} ; 125.5-123.1 \mathrm{~m}), \mathrm{K} / \mathrm{Pg}$ boundary at $410.7 \mathrm{ft}(125.2 \mathrm{~m})$ $(410-412 \mathrm{ft} ; 125-125.6 \mathrm{~m})$.

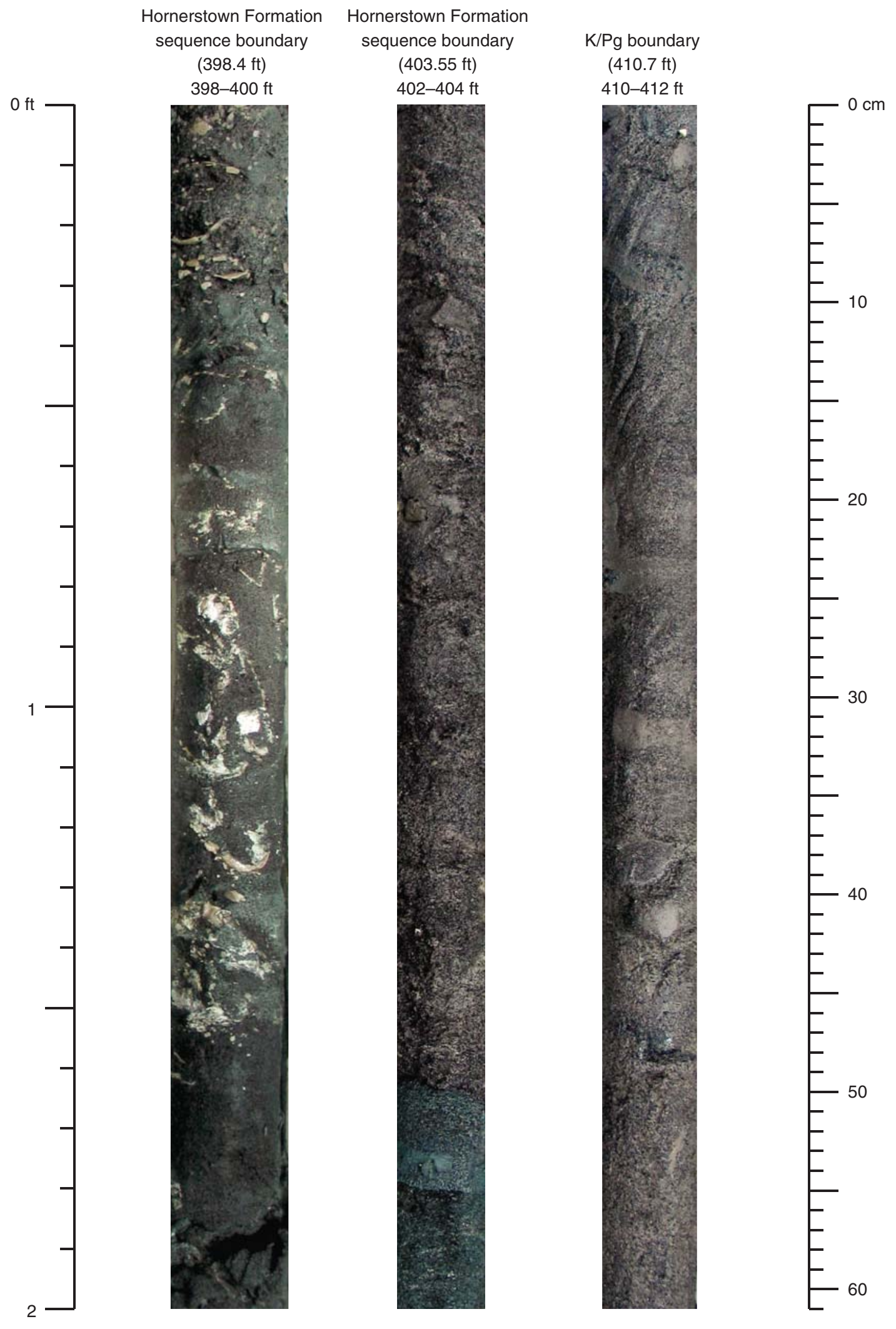


Figure F15. $\delta^{13} \mathrm{C}$ correlations of the PETM sections from Southern Ocean Site 690 (Bains et al., 1999), Millville, New Jersey (Wright and Schaller, 2013 ), and Wilson Lake, New Jersey (Wright and Schaller, 2013). Modified after Miller and Wright (2017). GSSP = global stratotype section and point.

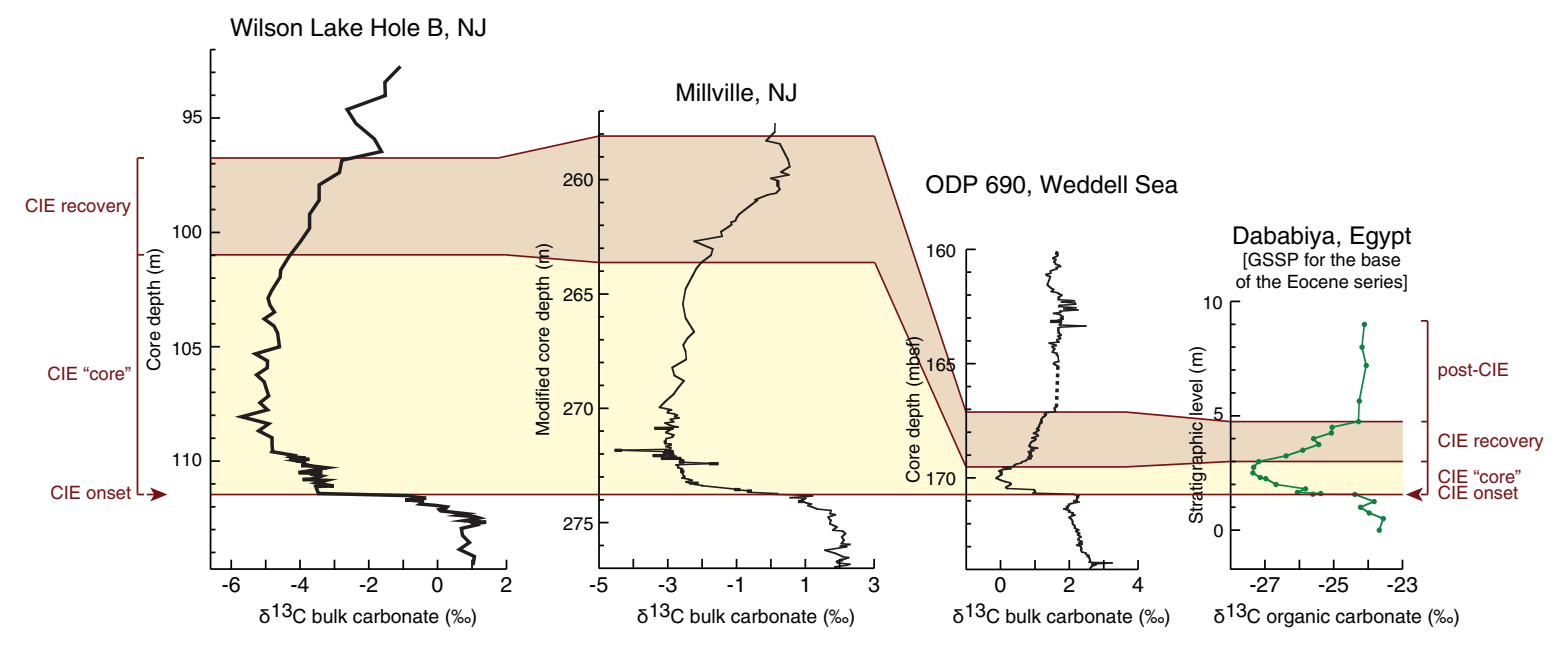

Table T1. Core descriptions, Wilson Lake site. Download table in CSV format.

Table T2. Percentages of grains, Wilson Lake site. Download table in CSV format.

Table T3. Planktonic foraminifers in the Shark River formation, Wilson Lake site. Download table in CSV format.

Table T4. Planktonic foraminifers from Paleocene/Eocene Thermal Maximum to Danian, Wilson Lake site. Download table in CSV format.

Table T5. Benthic foraminifers, Wilson Lake site. Download table in CSV format.

Table T6. Carbon isotopes, Wilson Lake site. Download table in CSV format.

Table T7. Sr isotopic data, Wilson Lake site. Download table in CSV format. 